\title{
Temporally delineated sources of major chemical species in high Arctic snow
}

\author{
Katrina M. Macdonald ${ }^{1}$, Sangeeta Sharma ${ }^{2}$, Desiree Toom ${ }^{2}$, Alina Chivulescu ${ }^{2}$, Andrew Platt $^{2}$, Mike Elsasser ${ }^{2}$, \\ Lin Huang ${ }^{2}$, Richard Leaitch ${ }^{2}$, Nathan Chellman ${ }^{3}$, Joseph R. McConnell ${ }^{3}$, Heiko Bozem ${ }^{4}$, Daniel Kunkel ${ }^{4}$, \\ Ying Duan Lei ${ }^{1}$, Cheol-Heon Jeong ${ }^{1}$, Jonathan P. D. Abbatt ${ }^{5}$, and Greg J. Evans ${ }^{1}$ \\ ${ }^{1}$ Department of Chemical Engineering and Applied Chemistry, University of Toronto, Toronto, M5S 3E5, Canada \\ ${ }^{2}$ Climate Research Division, Environment and Climate Change Canada, Toronto, M3H 5T4, Canada \\ ${ }^{3}$ Desert Research Institute, Reno, 89512, USA \\ ${ }^{4}$ Institute for Atmospheric Physics, Johannes Gutenberg University Mainz, Becher Weg 21, 55128 Mainz, Germany \\ ${ }^{5}$ Department of Chemistry, University of Toronto, Toronto, M5S 3H6, Canada
}

Correspondence: Greg J. Evans (greg.evans@utoronto.ca)

Received: 2 August 2017 - Discussion started: 14 August 2017

Revised: 16 December 2017 - Accepted: 26 January 2018 - Published: 9 March 2018

\begin{abstract}
Long-range transport of aerosol from lower latitudes to the high Arctic may be a significant contributor to climate forcing in the Arctic. To identify the sources of key contaminants entering the Canadian High Arctic an intensive campaign of snow sampling was completed at Alert, Nunavut, from September 2014 to June 2015. Fresh snow samples collected every few days were analyzed for black carbon, major ions, and metals, and this rich data set provided an opportunity for a temporally refined source apportionment of snow composition via positive matrix factorization (PMF) in conjunction with FLEXPART (FLEXible PARTicle dispersion model) potential emission sensitivity analysis. Seven source factors were identified: sea salt, crustal metals, black carbon, carboxylic acids, nitrate, noncrustal metals, and sulfate. The sea salt and crustal factors showed good agreement with expected composition and primarily northern sources. High loadings of $\mathrm{V}$ and Se onto Factor 2, crustal metals, was consistent with expected elemental ratios, implying these metals were not primarily anthropogenic in origin. Factor 3, black carbon, was an acidic factor dominated by black carbon but with some sulfate contribution over the winter-haze season. The lack of $\mathrm{K}^{+}$associated with this factor, a Eurasian source, and limited known forest fire events coincident with this factor's peak suggested a predominantly anthropogenic combustion source. Factor 4, carboxylic acids, was dominated by formate and acetate with a moderate correlation to available sunlight and an oceanic
\end{abstract}

and North American source. A robust identification of this factor was not possible; however, atmospheric photochemical reactions, ocean microlayer reaction, and biomass burning were explored as potential contributors. Factor 5, nitrate, was an acidic factor dominated by $\mathrm{NO}_{3}^{-}$, with a likely Eurasian source and mid-winter peak. The isolation of $\mathrm{NO}_{3}^{-}$ on a separate factor may reflect its complex atmospheric processing, though the associated source region suggests possibly anthropogenic precursors. Factor 6, non-crustal metals, showed heightened loadings of $\mathrm{Sb}, \mathrm{Pb}$, and $\mathrm{As}$, and correlation with other metals traditionally associated with industrial activities. Similar to Factor 3 and 5, this factor appeared to be largely Eurasian in origin. Factor 7, sulfate, was dominated by $\mathrm{SO}_{4}^{2-}$ and MS with a fall peak and high acidity. Coincident volcanic activity and northern source regions may suggest a processed $\mathrm{SO}_{2}$ source of this factor.

\section{Introduction and background}

Observations of Arctic climate have shown pronounced changes over recent years, including a rapid rise in surface temperature and the loss of sea ice and snow cover, with adverse local and global consequences (AMAP, 2017; Hartmann et al., 2013). Such changes in Arctic climate have been tied to contaminants within the Arctic atmosphere and snow, especially light-absorbing compounds such as black carbon 
(BC) which can warm the surface and atmosphere (Clarke and Noone, 1985; Hansen and Nazarenko, 2004; Bond et al., 2013; Jiao et al., 2014). Furthermore, studies have found the long-range transport of lower-latitude anthropogenic and natural emissions to be a significant and substantial contributor to the Arctic aerosol burden (Stohl, 2006; Law and Stohl, 2007; AMAP, 2015). Thus, understanding the sources of these pollutants is a critical step in the development of control and mitigation strategies to protect the vulnerable Arctic environment.

The lower troposphere of the Arctic is separated from the upper and southerly atmosphere by a transport barrier known as the "Arctic front" or "Arctic dome". This dome is formed by surfaces of constant potential temperature, which inhibit the transport of southerly air masses into the lower Arctic troposphere, instead forcing northward-travelling air masses to rise over the dome. The size and location of the Arctic front is a complex system driven by global atmospheric conditions, with significant variation by season. Over the summer, the Arctic front is typically northward of $70^{\circ} \mathrm{N}$; however, during the winter the Arctic front extends farther south, as far as $40^{\circ} \mathrm{N}$ (Stohl, 2006; Law and Stohl, 2007; AMAP, 2015). The Arctic front is also zonally asymmetric, typically extending much farther south over Eurasia during the winter. Thus, the Arctic atmosphere is more vulnerable to transport from southerly sources in the winter than the summer, especially Eurasian sources. Particles entering the Arctic atmosphere in winter can be removed only by atmospheric transport or deposition in snow where they can be retained for an extended time; thus, Arctic snow is a potentially critical reservoir within the Arctic system (AMAP, 2006). Given the seasonal variability in Arctic aerosol inputs and outputs, a period of enhanced accumulation is typically experienced during the Arctic winter and early spring termed "Arctic haze". The haze is primarily composed of sulfate $\left(\mathrm{SO}_{4}^{2-}\right)$ and organic particulate matter with varying levels of ammonium $\left(\mathrm{NH}_{4}^{+}\right)$, nitrate $\left(\mathrm{NO}_{3}^{-}\right)$, mineral dust, and BC (Mitchell, 1957; Shaw and Wendler, 1972; Rahn et al., 1977; Barrie, 1986; AMAP, 2006; Quinn et al., 2007, and the references therein).

Interest in Arctic aerosol increased after the first observations of Arctic haze in the 1950s (Mitchell, 1957; AMAP, 2006), and intensive routine monitoring of the Arctic atmosphere dates back to the late 1970s, particularly monitoring of $\mathrm{BC}$ and $\mathrm{SO}_{4}^{2-}$ (Barrie et al., 1981). However, direct measurements of pollutants in Arctic snow have been less common, particularly sampling campaigns of fresh snow. The relative abundance of Arctic aerosol data has facilitated extensive research on particulate sources (e.g., Sirois and Barrie, 1999; Stohl et al., 2013; Nguyen et al., 2013; Yttri et al., 2014). Fewer studies have identified the sources of snow impurities, which represent the deposited and surface albedoinfluencing portion of the aerosol, and often these studies are reliant on modelled snow concentrations (e.g., Skeie et al., 2011; Wang et al., 2011) rather than measurements (e.g., Hegg et al., 2009, 2010). Also, variability has been seen across existing snow apportionment studies. For example, previous studies show significant disagreement in the apportionment of $\mathrm{BC}$ during the Arctic winter, ranging from approximately 10 to over $90 \%$ attributed to biomass burning (e.g., Wang et al., 2011 and e.g., Hegg et al., 2009, respectively). To the best of the authors' knowledge, no quantitative source apportionment has previously been conducted using temporally refined fresh Arctic snow samples. Given the critical consequences arising from the deposition of $\mathrm{BC}$ and other impurities in snow, source apportionment specifically of these deposited chemical species is an important step towards understanding the Arctic environment. In this context, this paper analyzes the sources of chemical components in freshly fallen snow samples collected over a complete fall-winter-spring at a Canadian High Arctic location (Alert, Nunavut) and analyzed for a broad suite of analytes, using a combination of positive matrix factorization (PMF) diagnostics and Lagrangian dispersion modelling.

\section{Methodology}

\subsection{Snow sample collection and analysis}

Sample collection and analysis was completed as per Macdonald et al. (2017). Briefly, fresh snow samples were collected at Alert, Nunavut $\left(82^{\circ} 30^{\prime} \mathrm{N}, 62^{\circ} 20^{\prime} \mathrm{W}\right)$, from 14 September 2014 to 1 June 2015 from two snow tables located in an open-air minimal traffic site, about $1 \mathrm{~km} \mathrm{SSW}$ of the Alert base camp. Replicate samples were collected after each snowfall, weather permitting, to a total of 59 sets of samples ranging from 1 to 19 days between samples with an average of 4 days. The use of a snow table allowed the deposition area associated with each sample to be recorded and used along with sample volume in the conversion of measured concentration to flux. High winds in January and February may have led to undercatch of snow on the snow tables, underestimating the calculated flux; however, snow composition measurements on these dates is not believed to have been impacted. Further details on the sampling methodology are provided in the Supplement Sect. S1.

Snow samples were analyzed for BC via single particle soot photometry (SP2), major ions via ion chromatography (IC) and $\mathrm{pH}$ analyzer, and soluble and insoluble metals via inductively coupled plasma mass spectrometry (ICP-MS). A summary of the analysis methodology is provided in Supplement Sect. S1.2, with further detail provided in Macdonald et al. (2017). Stringent quality assurances were followed throughout snow collection and analysis. The uncertainty of each measurement was estimated based on analysis detection limits and reproducibility as follows (Reff et al., 2007; Norris et al., 2014): 


\subsection{Computational analyses}

$u_{i j}=\sqrt{\left(\mathrm{EF}_{j} x_{i j}\right)^{2}+\left(\frac{1}{2} \mathrm{MDL}_{j}\right)^{2}}$, if $x_{i j} \geq \mathrm{MDL}_{j}$,

$u_{i j}=\frac{5}{6} \mathrm{MDL}_{j}$, if $x_{i j}<\mathrm{MDL}_{j}$,

$u_{i j}=4 \bar{X}_{j}$, if $x_{i j}$ is missing,

Two approaches to source identification were used. Source type was explored via measurement apportionment to identify the source composition and seasonal contribution. Source location was explored via backward particle dispersion modelling.

\subsubsection{Source apportionment}

where $x_{i j}$ is the $i$ th measured value of analyte $j, u_{i j}$ is the uncertainty associated with this measurement, $\mathrm{EF}_{j}$ is the error fraction for this analyte, $\bar{X}_{j}$ is the median measurement for this analyte, and $\mathrm{MDL}_{j}$ is the method detection limit for this analyte.

The error fraction of each analyte was calculated as double the standard error of replicate measurements for each analysis, with a minimum of $10 \%$ imposed (Macdonald et al., 2017, as per Hegg et al., 2010). The method detection limit of each analyte was calculated as three standard deviations of analyzed blank samples. The uncertainty for any samples with known preparation concerns was doubled (e.g., partial sample melt in transit or poor mass closure over preparation); however, less than $7 \%$ of samples were noted as having potential preparation concerns.

The signal-to-noise ratio $(S / N)$ of each analyte was also calculated to indicate the strength of each measurement. Given the enhanced uncertainty of below MDL and missing values, these data points were excluded from the analysis per the suggestion of Norris et al. (2014) for environmental data. A $S / N$ over 2 was considered to be strong, while a $S / N$ from 0.2 to 2 was considered weak (Paatero and Hopke, 2003).

$S / N_{j}=\frac{1}{n} \sum_{i=1}^{n} d_{i j}$,

$d_{i j}=\frac{x_{i j}-u_{i j}}{u_{i j}}$, if $x_{i j}>u_{i j}$,

Positive matrix factorization is a numerical technique for describing speciated data as factors with associated compositional and temporal profiles. This study uses the most recent US EPA version, PMF5, which uses the multilinear engine ME2 to solve the following equation set (Norris et al., 2014):

$\mathbf{X}=\mathbf{G} \cdot \mathbf{F}+\mathbf{E}, \quad x_{i j}=\sum_{p=1}^{q} g_{i p} \cdot f_{p j}+e_{i j}$,

$Q=\sum_{i=1}^{n} \sum_{j=1}^{m}\left(\frac{e_{i j}}{u_{i j}}\right)^{2}$,

where $\mathbf{X}$ is the $n$ by $m$ matrix of measurements with associated uncertainties $u$; $\mathbf{G}$ is the calculated $n$ by $q$ matrix of factor contributions; $\mathbf{F}$ is the calculated $q$ by $m$ matrix of factor compositions; $\mathbf{E}$ is the $n$ by $m$ error matrix, with lower case variables representing the specific value therein for the $i$ th sample of the $j$ th analyte for the $p$ th factor; and $Q$ is the object function.

So, for any data set with $n$ measurements of $m$ analytes a solution is found for the matrices $\mathbf{G}$ and $\mathbf{F}$ for a particular number of factors, $q$, which produces the minimum value of $Q$, an optimization parameter calculated as the summed residual error, $e$, weighted by the measurement uncertainty, $u$. An additional $10 \%$ uncertainty was applied to all measurements in the PMF analysis, beyond that uncertainty captured in Eq. (1), to account for extra modelling uncertainty and further reduce the impact of noise. Any missing measurements were replaced with the median measured value (Norris et al., 2014). To determine the optimal number of factors, $q$, trial runs ranging from 2 to 9 factors were completed using 100 distinct random seeds per run. Trials were compared in terms of relative $Q$ value, improvement of solution with each additional factor, solution reproducibility, solution fit, and solution interpretability. Only solutions which produced factor profiles which could be explained in a real-world setting were considered. Random error and rotational ambiguity of the selected solution was explored by rerunning with 500 seeds, analysis of $G$-space plots, and quantification via the bootstrap error model. Supplement Sect. S1.2 provides further details on the PMF analysis.

The number of measurements included, $n$, was limited to dates with sufficient snowfall to complete the majority of analyses. Given the limited number of snow measurements available, a subset of the analyzed chemical species was used 
for PMF analysis. Only analytes with over $60 \%$ of measurements above MDL and strong $S / N$ were included in the analysis. Analytes of particular interest to this study with sufficient $S / N$ but only 30-60\% of measurements greater than MDL were included in some cases but defined as weak variables (i.e., user-defined uncertainty was tripled for these analytes). Analytes which duplicated others were also excluded from the PMF analysis, such as analytes measured by two methods (e.g., IC and ICP-MS overlapping analytes) and analytes which are expected to share a common source and show extremely strong correlations (e.g., crustal metals with no significant anthropogenic source). Duplicate and closely related analytes do not provide additional information to the apportionment study but artificially inflate the importance of these analytes and increase the ratio of analytes to measurements unnecessarily. The complete list of chemical species included in each analysis is provided with the results.

\subsubsection{Transport modelling}

The Lagrangian particle dispersion model FLEXPART (FLEXible PARTicle dispersion model), described in detail by Stohl et al. (2005), has been shown to be an effective tool for the prediction of transport pathways into and within the Arctic (e.g., Stohl, 2006; Paris et al., 2009). This potential emission sensitivity analysis was completed to identify likely source locations, as a complement to the PMF descriptions of source type. Modelled tracers were initialized over Alert and tracked backwards in time over a 10-day period at a $3 \mathrm{~h}$ time step, driven using operational analysis data from the European Centre for Medium-Range Weather Forecasts with a horizontal resolution of $0.25^{\circ}$ in longitude and latitude and 137 vertical hybrid pressure levels. Tracers were initialized at four altitudes over Alert: 100, 500, 1000, and $2000 \mathrm{~m}$ above sea level. A simulation was completed for every 5 days over the campaign. Simulation results provided the expected residence time of the tracers at the horizontal resolution of the meteorological input data and on 10 levels up to $10 \mathrm{~km}$.

The potential FLEXPART source regions associated with each PMF factor were identified. The peak periods associated with each factor, selected as the top 90th percentile of the factor contribution time series, were used to weight the FLEXPART 10-day residence times over the campaign, as per Eq. (4):

$t_{p}^{x y}=\frac{\sum_{i=1}^{n} g_{i p}^{\prime} t_{i}^{x y}}{\sum_{i=1}^{n} g_{i p}^{\prime}}$,

$g_{i p}^{\prime}=g_{i p}$, if $g_{i p} \geq g_{p}^{90}$ else, $g_{i p}^{\prime}=0$

where $t_{p}^{x y}$ is the residence time at location $x, y$ for the $p$ th PMF factor; $t_{i}^{x y}$ is the $i$ th residence time at location $x, y ; g_{i p}^{\prime}$ is the 90th percentile contributions of the $p$ th factor at time $i ; g_{p}^{90}$ is the 90th percentile of $g_{p}$; and all other variables are as per Eq. (3).
Only trajectories within 500 m of ground level were considered, given that low-altitude air masses are much more likely to show the influence of ground-level sources; however, selection of this $500 \mathrm{~m}$ cut-off height was found to have a negligible impact as the identified potential source regions were similar if it was adjusted in a sensitivity analysis by $\pm 300 \mathrm{~m}$; although, source regions for a higher cut-off height were expanded over a larger area. The weighted sum was then plotted to depict regions which likely influenced each factor. It should be noted that this approach will highlight the Arctic as a potential source for all factors given that all air masses were initialized at Alert within $500 \mathrm{~m}$ of the surface. Thus, interpretation of these plots must consider that they highlight both possible source regions as well as regions the air mass entered en route to Alert. Furthermore, factors with similar peaks will produce similar plots; however, it was found that no factor of the selected solution shared more than two dates with peaks above their respective 90th percentile.

\section{Results and discussion}

\subsection{Optimal PMF solution}

Positive matrix factorization was completed on 49 measurements of 20 analytes in Arctic snow (as listed in Table 1). Analysis of snow measurements as flux per period (i.e., the total deposited mass per area per snowfall) was found to be the most readily interpreted as physically realistic factors. PMF analyses of the snow measurements as concentration and flux per day are presented in the Supplement Sect. S3. Based on the criteria outlined in Sect. 2.2.1, a seven-factor solution was found to be optimal. The seven-factor solution produced one of the largest $Q$-value improvements with the addition of a factor, an acceptable relative $Q$ value, and good reproducibility. In particular, the seven-factor solution showed a marked improvement in fit and interpretability over solutions with fewer factors. The seven-factor solution reproduced measurements with a Pearson's correlation coefficient above 0.8 for all strong analytes. Furthermore, a repeat run using 500 seeds showed the seven-factor solution to be consistent and stable. The Supplement Sect. S2 provides additional details on solution selection and the evolution of factor profiles over the completed runs. A brief overview of the results of the four- and six-factor solutions is provided in the Supplement, as these solutions also showed merit as realistic apportionments of the data, although with poorer predictedmeasured fit and residual error. Potential rotated solutions were considered but showed no improvement over the unrotated base solution. The final solution statistics are summarized in the Supplement Sect. S2.3. The input and model diagnostic parameters for each analyte included in this PMF analysis are provided in Table 1. Only the portions considered as insoluble for metals measured by ICP-MS were included in this analysis ( $\mathrm{Al}, \mathrm{V}, \mathrm{Cu}, \mathrm{As}, \mathrm{Se}, \mathrm{Sb}$, and Pb). Resid- 
Table 1. Overview of PMF seven-factor solution input and diagnostic properties.

\begin{tabular}{|c|c|c|c|c|c|c|}
\hline \multirow[t]{2}{*}{ Analyte } & \multicolumn{3}{|c|}{ Input properties } & \multicolumn{3}{|c|}{ Diagnostic properties } \\
\hline & $\begin{array}{l}\text { MDL } \\
(\mathrm{ppb})\end{array}$ & $\begin{array}{r}\text { Missing } \\
\text { data }\end{array}$ & $\begin{array}{r}\text { Data below } \\
\text { MDL }\end{array}$ & $\begin{array}{l}\text { Predicted- } \\
\text { measured fit }\end{array}$ & $\begin{array}{r}\text { Normalized } \\
\text { residual mean }\end{array}$ & $\begin{array}{l}\text { Normalized } \\
\text { residual deviation }\end{array}$ \\
\hline \multicolumn{7}{|c|}{ Strong analytes } \\
\hline $\mathrm{BC}$ & 0.042 & $0 \%$ & $0 \%$ & 1.00 & 0.01 & 0.20 \\
\hline ACE & 4.4 & $0 \%$ & $4 \%$ & 0.90 & 0.08 & 0.85 \\
\hline FOR & 1.2 & $0 \%$ & $0 \%$ & 0.83 & 0.13 & 0.77 \\
\hline $\mathrm{Cl}^{-}$ & 18 & $0 \%$ & $0 \%$ & 0.96 & 0.03 & 0.43 \\
\hline $\mathrm{NO}_{3}^{-}$ & 5.0 & $0 \%$ & $4 \%$ & 0.99 & 0.01 & 0.22 \\
\hline $\mathrm{SO}_{4}^{2-}$ & 18 & $0 \%$ & $0 \%$ & 0.99 & 0.01 & 0.20 \\
\hline $\mathrm{Na}^{+}$ & 18 & $0 \%$ & $4 \%$ & 0.99 & 0.02 & 0.38 \\
\hline $\mathrm{NH}_{4}^{+}$ & 5.0 & $0 \%$ & $2 \%$ & 0.85 & 0.07 & 0.65 \\
\hline $\mathrm{K}^{+}$ & 5.0 & $0 \%$ & $12 \%$ & 0.77 & 0.25 & 1.11 \\
\hline $\mathrm{Mg}^{2+}$ & 18 & $0 \%$ & $22 \%$ & 0.95 & 0.03 & 0.54 \\
\hline $\mathrm{Al}$ & 30 & $8 \%$ & $27 \%$ & 0.99 & 0.00 & 0.42 \\
\hline $\mathrm{V}$ & 0.027 & $8 \%$ & $10 \%$ & 0.97 & 0.09 & 0.57 \\
\hline As & 0.010 & $8 \%$ & $0 \%$ & 0.93 & 0.09 & 0.76 \\
\hline $\mathrm{Se}$ & 0.084 & $8 \%$ & $16 \%$ & 0.99 & 0.01 & 0.43 \\
\hline $\mathrm{Sb}$ & 0.013 & $8 \%$ & $0 \%$ & 0.87 & 0.17 & 0.95 \\
\hline $\mathrm{Pb}$ & 0.16 & $8 \%$ & $8 \%$ & 0.97 & 0.05 & 0.67 \\
\hline \multicolumn{7}{|c|}{ Weak analytes } \\
\hline MS & 1.9 & $0 \%$ & $73 \%$ & 0.70 & 0.11 & 0.53 \\
\hline $\mathrm{Br}^{-}$ & 5.0 & $0 \%$ & $53 \%$ & 0.46 & 0.09 & 0.49 \\
\hline $\mathrm{C}_{2} \mathrm{O}_{4}^{2-}$ & 18 & $0 \%$ & $63 \%$ & 0.76 & 0.01 & 0.18 \\
\hline $\mathrm{Cu}$ & 0.23 & $8 \%$ & $20 \%$ & 0.49 & 0.13 & 0.55 \\
\hline
\end{tabular}

Notes: ACE, acetate; FOR, formate; MS, methanesulfonate. Predicted-measured fit presented is Pearson's correlation coefficient. Metals with a charge are those measured by IC; others are insoluble portions measured by ICP-MS.

uals of all analytes were found to be normally distributed, based on PMF5's Kolmogorov-Smirnov test, with the exception of $\mathrm{NO}_{3}^{-}$and $\mathrm{V}$, although both appear visually to be close to a normal distribution.

\subsection{Factor discussion}

The seven PMF factors are described by their composition (Fig. 1), contribution over time (Fig. 2), and potential areas of influence and/or source regions (Fig. 3). Error estimates provided for the percent apportionment of each analyte are the 25 th and 75 th bootstrap analysis percentiles. The bootstrap analysis correctly mapped over $96 \%$ of subsampled data for each factor, with the exception of Factor 7 which was correctly mapped for $76 \%$ of the bootstrapped runs. Furthermore, sensitivity runs and additional analysis (as described in the Supplement) corroborated the presented results. Details on the solution sensitivity and validation analysis are provided in the Supplement.

The possible identities of each factor were suggested based on their composition, time series, correlations with non-apportioned analytes (i.e., analytes which were not included in the PMF apportionment) or with other mea- sured parameters such as meteorology, and source regions. Table 2 summarizes the dominant analytes associated with each factor and their approximate breakdown of potential influencing regions. A neutralization ratio is also presented for each factor (i.e., $\left[\mathrm{Na}^{+}+\mathrm{NH}_{4}^{+}+\mathrm{K}^{+}+\mathrm{Mg}^{2+}\right]$ $/\left[\mathrm{MS}+\mathrm{ACE}+\mathrm{FOR}+\mathrm{Cl}^{-}+\mathrm{Br}^{-}+\mathrm{NO}_{3}^{-}+\mathrm{SO}_{4}^{2-}+\mathrm{C}_{2} \mathrm{O}_{4}^{2-}\right]$, all as equivalence $\mathrm{m}^{-2}$ period ${ }^{-1}$ ). Finally, non-apportioned analytes and other measured parameters were correlated against the factor contribution time series and notable correlations are included in Table 2 below (Pearson's correlations greater than 0.7 are considered strong and greater than 0.3 weak; listed in descending order).

The factor characteristics and possible identifications are discussed in greater detail in the following sections.

\subsubsection{Factor 1: sea salt}

Factor 1 was found to resemble sea salt, primarily based on its composition. The first factor was characterized by high loadings ( $>75 \%$ of total flux mass apportioned to Factor 1) of $\mathrm{Na}^{+}$and $\mathrm{Cl}^{-}$and $30-45 \%$ mass $/$ mass $(\mathrm{m} / \mathrm{m})$ loadings of $\mathrm{Br}^{-}, \mathrm{K}^{+}$, and $\mathrm{Mg}^{2+}$ (Fig. 1; Table 2). These dominant analytes and their relative proportions are consistent 
Table 2. Overview of factor characteristics.

\begin{tabular}{|c|c|c|c|c|c|c|c|c|}
\hline \multirow[t]{2}{*}{ Factor } & \multirow[t]{2}{*}{$\begin{array}{l}\text { Dominant } \\
\text { composition }\end{array}$} & \multicolumn{4}{|c|}{$\begin{array}{c}\text { Source and/or influence regions } \\
\text { (\% residence time) }\end{array}$} & \multirow[t]{2}{*}{$\begin{array}{r}\text { Neutralization } \\
\text { ratio }\end{array}$} & \multirow[t]{2}{*}{$\begin{array}{l}\text { Peak } \\
\text { period(s) }\end{array}$} & \multirow[t]{2}{*}{$\begin{array}{l}\text { Correlated } \\
\text { parameters }\end{array}$} \\
\hline & & Arctic & $\begin{array}{r}\text { North } \\
\text { America }\end{array}$ & Eurasia & $\begin{array}{r}\text { Open } \\
\text { ocean }\end{array}$ & & & \\
\hline (1) Sea salt & $\mathrm{Na}^{+}, \mathrm{Cl}^{-}$ & $84 \%$ & $1 \%$ & $14 \%$ & $2 \%$ & $0.79[0.75-0.84]$ & episodic & Weak: period length \\
\hline (2) Crustal metals & $\mathrm{Al}, \mathrm{V}, \mathrm{Se}$ & $92 \%$ & $1 \%$ & $5 \%$ & $2 \%$ & $1.54[1.17-2.11]$ & episodic & $\begin{array}{l}\text { Strong: } \mathrm{Fe}, \mathrm{Mn}, \mathrm{Co} \\
\text { Weak: } \mathrm{Ca}^{2+}, \mathrm{Ti}, \quad \text { base } \\
\text { camp winds }\end{array}$ \\
\hline (3) Black carbon & $\mathrm{BC}$ & $85 \%$ & $0 \%$ & $14 \%$ & $1 \%$ & $0.12[0.17-0.38]$ & winter & $\begin{array}{l}\text { Weak: Ti, As (soluble) } \\
\text { Anti-corr.: temp. }\end{array}$ \\
\hline (4) Carboxylic acids & FOR, ACE & $94 \%$ & $2 \%$ & $1 \%$ & $3 \%$ & $1.02[0.56-1.24]$ & fall/spring & $\begin{array}{l}\text { Weak: } \mathrm{Ba} \text {, base camp } \\
\text { winds, propionate, sun- } \\
\text { light }\end{array}$ \\
\hline (5) Nitrate & $\mathrm{NO}_{3}^{-}$ & $83 \%$ & $0 \%$ & $16 \%$ & $1 \%$ & $0.04[0.03-0.19]$ & episodic & Weak: $\mathrm{Ti}, \mathrm{H}^{+}, \mathrm{NO}_{2}^{-}$, \\
\hline (6) Non-crustal metals & $\mathrm{Sb}, \mathrm{Pb}, \mathrm{As}$ & $82 \%$ & $0 \%$ & $17 \%$ & $1 \%$ & $0.36[0.30-0.60]$ & episodic & Weak: Ti, As (soluble) \\
\hline (7) Sulfate & $\mathrm{SO}_{4}^{2-}, \mathrm{MS}$ & $91 \%$ & $3 \%$ & $6 \%$ & $1 \%$ & $0.17[0.15-0.30]$ & fall & $\begin{array}{l}\text { Strong: } \mathrm{NO}_{2}^{-} \\
\text {Weak: } \mathrm{H}^{+}, \mathrm{Ba}, \mathrm{Ca}^{2+} \text {, tem- } \\
\text { perature, sunlight }\end{array}$ \\
\hline
\end{tabular}

Notes: "Open ocean" is defined as areas of the Atlantic and Pacific below $65^{\circ} \mathrm{N}$. "Arctic" source area includes the northern Pacific and Atlantic Ocean, Arctic Ocean, Canadian High Arctic, and Greenland. Neutralization ratio is described as optimal solution [25t-75th bootstrapping]. Metals with a charge are those measured by IC; others are insoluble portions measured by ICP-MS unless noted as soluble.

with that of sea salt (Pytkowicz and Kester, 1971), suggesting a marine origin for Factor 1. The mass ratios of $\mathrm{Cl}^{-}$ and $\mathrm{K}^{+}$to $\mathrm{Na}^{+}$in Factor 1 were similar to that expected for sea salt with enrichment ratios close to unity of 1.3 and 1.1 , respectively (1.3-1.4 and 0.8-1.2 25th-75th percentiles per bootstrapping analysis). The mass ratios of $\mathrm{Mg}^{2+}$ and $\mathrm{SO}_{4}^{2-}$ to $\mathrm{Na}^{+}$also resembled that of sea salt, with enrichment ratios of 1.6 and 1.7, respectively (1.5-1.7 and 1.01.9 25th-75th percentiles per bootstrapping analysis). Their slight elevation above unity may indicate some enrichment of these ions in the marine aerosol or inclusion of a separate source; however, a $\mathrm{Mg}^{2+} / \mathrm{Na}^{+}$enrichment ratio of 1.6-1.7 was seen to be consistent among PMF analysis with more/fewer factors. These enrichment ratios agree well with those measured by Krnavek et al. (2012): 1.33, 1, and 1.4 for $\mathrm{Cl}^{-}, \mathrm{K}^{+}$, and $\mathrm{Mg}^{2+}$, respectively. The only sea salt analyte which was notably different from expected marine levels was $\mathrm{Br}^{-}$with an enrichment ratio of 3.4 (2.8-4.2 25th75th percentiles per bootstrapping analysis), which may indicate aerosol enrichment of $\mathrm{Br}^{-}$relative to $\mathrm{Na}^{+}$or may be a result of this analyte's high uncertainty and poor signalto-noise ratio. As shown in the Supplement Fig. S1, apportioned $\mathrm{Br}^{-}$was underestimated particularly in spring, suggesting that $\mathrm{Br}^{-}$spring photochemistry (as per that observed by Toom-Sauntry and Barrie, 2002; Pratt et al., 2013) is not well captured in this PMF analysis.

Factor 1 showed sporadic peaks throughout the campaign, with the largest peak early January (Fig. 2). The January peak coincided with a local blizzard, which may indicate local marine sources such as open water, blowing saline snow, or frost flowers. A strong correlation between high winds and salt emissions from fresh sea ice frost flowers has been suggested by others (e.g., Xu et al., 2013). However, Factor 1 also showed a moderate correlation with collection period length (Pearson's correlation coefficient of 0.47) and the noted January peak was one of the longest collection periods in the campaign. This may indicate continuous dry and/or wet deposition of sea salt to the snow table over time. Weighting the FLEXPART-predicted source areas by the Factor 1 peak dates (Fig. 3) showed the Eurasian coast of the Arctic Ocean, the Norwegian Sea, the Greenland Sea, and the northern Atlantic Ocean to be potential sources of sea salt to Alert. Icefree areas were identified using the NOAA G02135 ice concentration images (retrieved from ftp://sidads.colorado.edu/ DATASETS/NOAA/G02135/, November 2017). During periods of peak Factor 1 contribution the East Siberian Sea, Laptev Sea, and Kara Sea appeared to have been largely icecovered; however, the Barents Sea, Greenland Sea, Norwegian Sea, northern Atlantic, and portions of Baffin Bay and waters surrounding the Queen Elizabeth Islands all seem to have been ice-free or with new, thin ice coverage. Thus, sea salt spray from these areas likely contributed to the sea salt signal at Alert.

The marine factor was found to be highly robust over this apportionment analysis. All runs with more than two factors exhibited a resolved $\mathrm{Na}^{+}$and $\mathrm{Cl}^{-}$dominated factor, and the composition of this marine factor was found to be maintained across each addition of a new factor with Pearson's correlation coefficients above 0.98 . Bootstrapping analysis found little error associated with this factor. Furthermore, similar marine factors have been observed in previous apportionment studies of Arctic snow (Hegg et al., 2009, 2010) and Arctic aerosol (Sirois and Barrie, 1999; Nguyen et al., 2013). 




Figure 1. Factor profiles. The loading of each analyte to each factor is provided as the portion of their flux apportioned to that factor as well as the percentage of the analyte's total flux (mass / mass) apportioned to that factor. Error bars on the percentage loading show the 25th and 75th percentiles of the bootstrapping analysis. Flux contributions below $0.00001 \mathrm{~g} \mathrm{~m}^{-2}$ period $^{-1}$ are not shown. Metals with a charge are those measured by IC; others are insoluble portions measured by ICP-MS.

\subsubsection{Factor 2: crustal metals}

Factor 2 was characterized by elevated levels of $\mathrm{Al}, \mathrm{V}$, and Se, all over $80 \%$ mass / mass loading, and $25-50 \%$ loading of $\mathrm{Cu}, \mathrm{As}, \mathrm{Mg}^{2+}$, and $\mathrm{Pb}$ (Fig. 1; Table 2). These metals suggest a crustal origin for this factor. The composition of dust is far more variable than that of sea salt; thus, no single enrichment ratio can be determined for each analyte mass ratio as loaded on to Factor 2. However, the modelled mass ratios of $\mathrm{Al}$ to $\mathrm{Mg}^{2+}, \mathrm{K}^{+}, \mathrm{V}, \mathrm{Cu}, \mathrm{As}, \mathrm{Se}, \mathrm{Sb}$, and $\mathrm{Pb}$ all appear realistic when compared with a variety of crustal sources, with calculated enrichment ratios in the range of 1 to 15 (Taylor, 1964; Barrie et al., 1989; Masson-Delmotte et al., 2013). Specifically, the modelled mass ratio of $\mathrm{As} / \mathrm{Al}(0.00081 \mathrm{~m} / \mathrm{m})$ was seen to be closer to that of local soils (0.00013) (Barrie et al., 1989) than the global typical composition (0.00002) (Taylor, 1964; Masson-Delmotte et al., 2013) with enrichment ratios of 6 and 37, respectively (6.3-9.5 and 37-58 25th- 75th percentiles per bootstrapping analysis). The composition of Factor 2, crustal metals, suggested an alkaline aerosol with a neutralization ratio of 1.5 , calculated as described in Sect. 3.2.

Factor 2 showed sporadic peaks over the campaign but primarily from November to February and after April. This time series showed good agreement with non-apportioned metals typically considered to be dominated by crustal origins: insoluble $\mathrm{Fe}, \mathrm{Mn}, \mathrm{Co}, \mathrm{Tl}$, and $\mathrm{Ca}$. The time series of this factor also showed slight correlations with winds from the direction of the base camp and winds speeds, with Pearson's correlations of 0.39 and 0.26 , respectively. This, along with the calculated As / Al mass ratio, suggests that this crustal factor may be dominated by local soil and dust, likely from cleared or paved areas at the Alert base camp. The potential source regions calculated from FLEXPART results for this factor are shown in Fig. 3. Arctic areas dominate the identified potential source region, again suggesting local soils were a major contributor to this factor; however, potential long-range sources of northern Asia, North America, and the Atlantic Ocean were also identified. A primarily local dust source is supported by the findings of Zwaaftink et al. (2016), which showed that surface dust loads within the high Arctic are typically dominated by Arctic sources with an annual average contribution of $70 \%$ deposited mass from sources above $60^{\circ} \mathrm{N}$

A factor dominated by crustal metals was consistently resolved among the completed apportionment runs. This factor maintained a fairly similar composition across all numbers of factors, with Pearson's correlation coefficients above 0.97 . However, metals traditionally considered to be associated with industrial activities, such as $\mathrm{Pb}, \mathrm{Cu}, \mathrm{As}$, and $\mathrm{Sb}$, were observed to gradually split from this factor with the addition of new factors. The seven-factor solution for this factor showed low levels of error according to the bootstrapping analysis. Similar factors have been observed in previous atmospheric apportionment studies (e.g., Sirois and Barrie, 1999; Nguyen et al., 2013) but typically were not seen to account for such a large percentage of these metals, i.e., with loadings of $25-60 \% \mathrm{~m} / \mathrm{m}$ for major crustal analytes. This might suggest that a separate source was missed by this study, though this seems unlikely given the consistency of the observed factor. Sirois and Barrie (1999) found the crustal signature at Alert to be dominated by local sources during the fall and long-range transport in the late spring to summer. This supports a single local source for this study focussed on the winter season, while studies of the full year may have split crustal analytes among various long-range transport sources. However, the April-May peak in the crustal factor observed in this study coincides with Sirois and Barrie's (1999) peak considered to be dominated by long-range dust transport. 


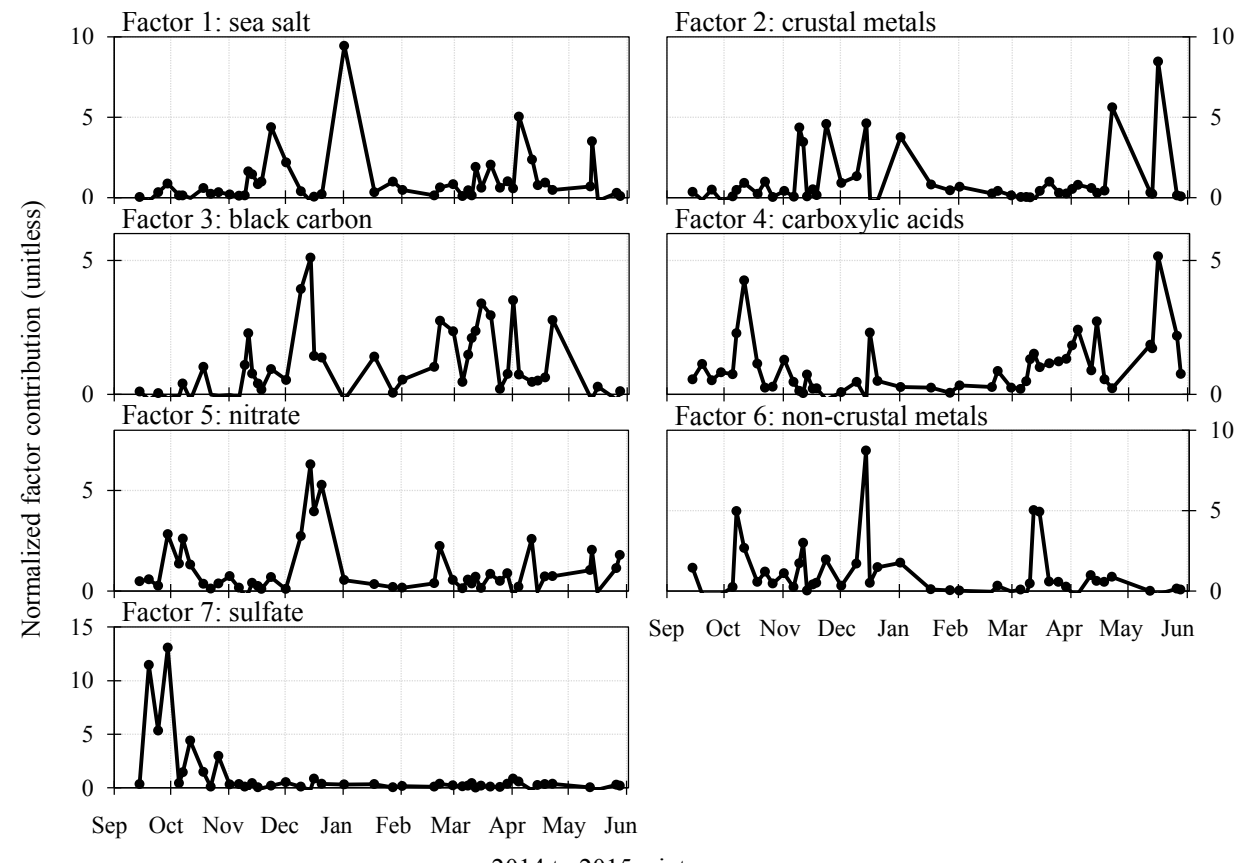

2014 to 2015 winter season

Figure 2. Normalized factor contributions. The unitless contributions describe the relative magnitude of each factor over time such that the average contribution of each factor is one. For example, for the snowfall in early January Factor 1 sea salt had a contribution that was approximately 10 times its average contribution over the campaign.

\subsubsection{Factor 3: black carbon}

The third factor was characterized by a high loading of $\mathrm{BC}$, $66 \% \mathrm{~m} / \mathrm{m}$ of the total $\mathrm{BC}, 17 \% \mathrm{~m} / \mathrm{m}$ loading of $\mathrm{NH}_{4}^{+}$, and all other analyte loads below $10 \%$ (Fig. 1). BC is a combustion product from both fossil fuel and biomass burning. While $\mathrm{NH}_{4}^{+}$is more commonly associated with agricultural emissions, it can also be produced by biomass burning, vehicle emissions, and some industrial activities (Behera et al., 2013). Most conspicuous in the composition of Factor 3 was the absence of $\mathrm{K}^{+}$, considered to be a tracer of biomass burning which can be a significant source of BC. This separation of $\mathrm{BC}$ - and $\mathrm{K}^{+}$-rich factors was persistent for all PMF solutions with four or more factors. Furthermore, the mass ratios of $\mathrm{SO}_{4}^{2-}$ and $\mathrm{NO}_{3}^{-}$to $\mathrm{BC}$ were much higher than would be expected for biomass burning with enrichment ratios above 10 (Turn et al., 1997; Hays et al., 2005; Saarikoski et al., 2007; McMeeking et al., 2009; May et al., 2014); the relative loading of $\mathrm{SO}_{4}^{2-}$ compared to $\mathrm{NH}_{4}^{+}$and $\mathrm{NO}_{3}^{-}$was also higher than expected for biomass burning (Liu et al., 2017). This factor also showed an acidic signature with a neutralization ratio of 0.12 . Factor 3, BC, showed an enhanced contribution over the Arctic haze season, November through April (Fig. 2). The time series of this factor did not show a strong correlation with any non-apportioned analyte; however, it did show weak correlations with insoluble Ti and V, and soluble As. The observed winter enhancement of this factor did not suggest a significant contribution from forest fires which are more prevalent in warmer months. Furthermore, the peaks in this factor did not coincide with dates of known Northern Hemisphere forest fire activity (as per fire records of NASA Global Fire Maps, retrieved May 2016 from https://lance.modaps.eosdis.nasa.gov). Thus, the composition and time series of Factor 3, BC, suggested a predominantly anthropogenic combustion source with little contribution from biomass burning. A BC-dominated factor was resolved for all runs with four or more factors, and its composition remained consistent with Pearson's correlation coefficients of 0.95 or greater. Thus, the practically unique origin of $\mathrm{BC}$ was fairly robust through this analysis.

There have been many studies exploring the sources of Arctic BC, though primarily focussed on aerosol. The relative importance of fossil fuel combustion and biomass burning differs between studies, likely indicating a strong dependence on location (especially high vs. low Arctic), season, or differences in source breakdown year to year (e.g., McConnell et al., 2007; Doherty et al., 2010; Dou et al., 2012; Law et al., 2014). A recent study by Xu et al. (2017) analyzing airborne measurement from a similar time period as this study found about $90 \%$ of BC to likely be anthropogenic in source, primarily from Eurasia, supporting the assessment above. Several modelling studies have suggested that combined anthropogenic sources account for 65 $96 \% \mathrm{~m} / \mathrm{m}$ of $\mathrm{BC}$ in Arctic snow, especially elevated over the winter months with spring and summer proportions dependent on the frequency of forest fires of that year (Flanner 


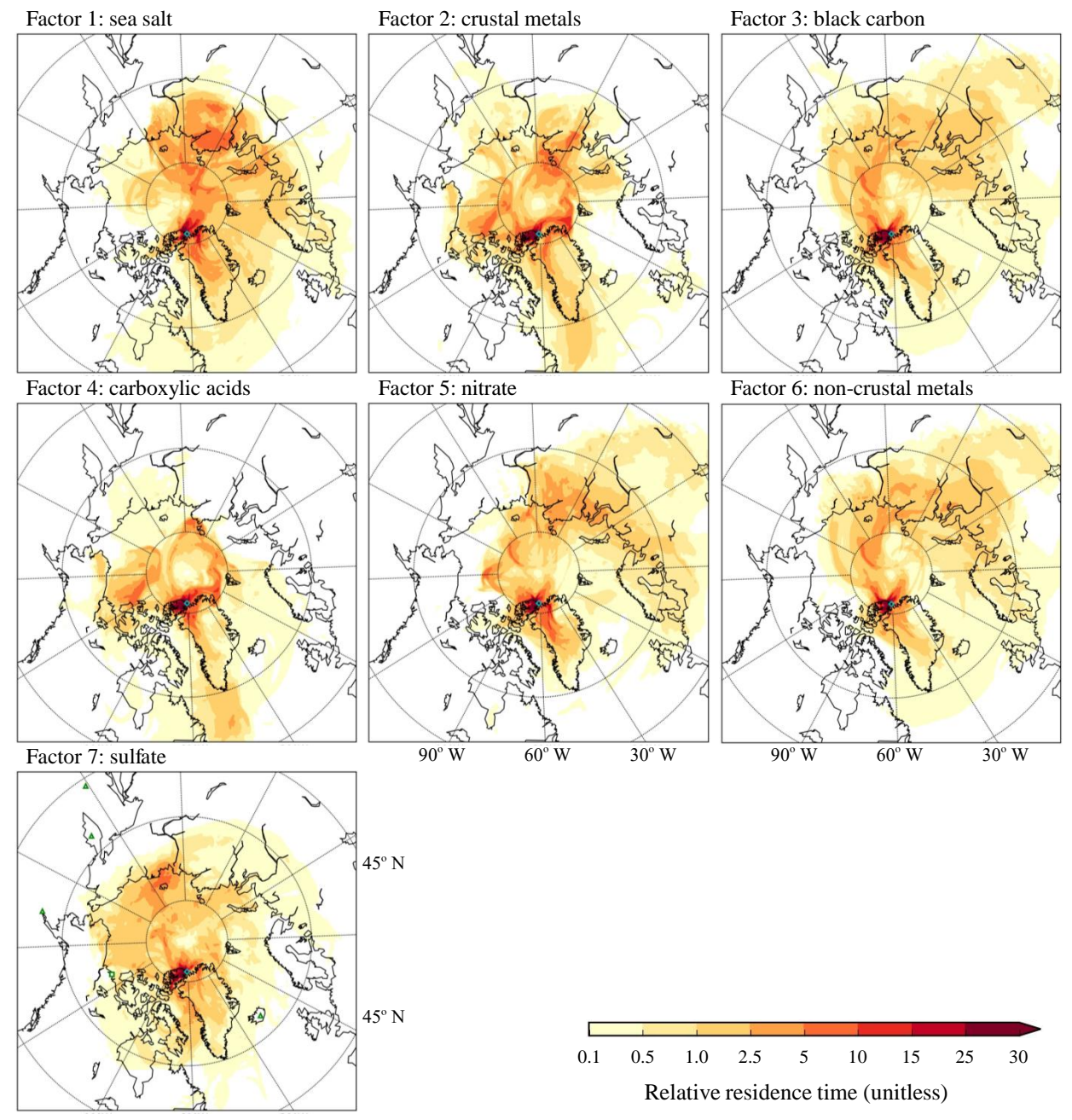

Figure 3. Potential 10-day area of influence and/or source regions of apportionment factors. Cyan diamonds on plot show the location of Alert, Nunavut. The Factor 7 sulfate plot depicts active volcanoes as green triangles and the Smoking Hills as a green square (Hunter, 2007).

et al., 2007; Skeie et al., 2011; Wang et al., 2011; Sharma et al., 2013; Breider et al., 2014; Xu et al., 2017). In particular, modelling studies have shown winter Arctic BC to be dominated by flaring and other mixed industry emissions, with less impact from anthropogenic biomass burning (Flanner et al., 2007; Stohl et al., 2013). Studies of Arctic snow and aerosol composition have suggested that over $85 \%$ of BC is from the combustion of fossil fuels year-round, based on radiocarbon analysis and measured mass ratios with biomass burning tracers (e.g., Slater et al., 2002; Yttri et al., 2011, 2014; Barret et al., 2015). Hegg et al. (2009, 2010) completed snow PMF apportionment analyses on spatially defined samples. Unlike the majority of studies discussed above, these apportionment studies of Arctic spring snowpack attributed over $90 \%$ of $\mathrm{BC}$ to biomass burning origins. The Hegg et al. $(2009,2010)$ studies showed the variability in BC sources to snow by location and season; however, in nearly all cases, including aged winter snow, pol- lution sources were found to be small contributors relative to biomass burning. This may indicate a significant fluctuation in BC sources between years; however, both the 2014 2015 season and the years of interest in the Hegg et al. studies $(2009,2010)$ were found to represent fairly typical years in Northern Hemisphere biomass burning emissions (Global Fire Emissions Database, version 4.1, retrieved July 2016 from http://www.globalfiredata.org). Thus, the findings of this study stress the variability in BC sources to Arctic snow and the importance of further measurements to better classify the main contributions.

Weighting of the FLEXPART results by the peak periods for Factor 3 indicated that central Eurasia was a probable source of this factor, especially northern Russia and some portions of central southern Russia (Fig. 3). Russian industrial activities are known to be a significant source of BC; in particular, some studies have estimated about $70 \%$ of Russian $\mathrm{BC}$ emissions are related to flaring and transporta- 
tion (Evans et al., 2017). These source regions correspond with known flaring and industrial BC sources (in the vicinity of the $\mathrm{Ob}$ and Pechora rivers and the Taymyrsky DolganoNenetsky District, respectively) (Huang et al., 2015; Winiger et al., 2017). A winter central Eurasian source of BC was also identified by Xu et al. (2017), specifically flaring in western Siberia. However, this central Asian source was found to be a smaller contributor of total Arctic BC than eastern Asia. Similarly, Hirdman et al. (2010) and Stohl et al. (2007) also identified a primarily northeastern Eurasian source to Arctic $\mathrm{BC}$ in the winter-late spring. The lack of a distinct eastern Asian source for Factor 3, BC, may indicate that the 10-day trajectory analysis was not long enough to fully capture this influence.

\subsubsection{Factor 4: carboxylic acids}

Factor 4 was characterized by high loadings, $79-80 \% \mathrm{~m} / \mathrm{m}$, of acetate (ACE) and formate (FOR); moderate loadings, 25$50 \%$, of $\mathrm{NH}_{4}^{+}$and $\mathrm{Br}^{-}$; and lower loadings, $10-20 \%$, of $\mathrm{Sb}$, $\mathrm{BC}$, and MS (Fig. 1; Table 2). The loadings of $\mathrm{Br}^{-}$and MS on this factor were highly variable, as shown by the bootstrap results in Fig. 1; however, both of these analytes had high associated uncertainty. The composition of this factor suggested a neutral aerosol with a neutralization ratio of 1.02 . Factor 4 exhibited peaks in October and May (Fig. 2) and was seen to moderately correlate with propionate, hours of sunlight, and base camp winds with Pearson's correlation coefficients of 0.4-0.5. Weighted FLEXPART results indicated local, North American, and Atlantic Ocean areas of potential influence for this factor (Fig. 3). A variety of potential source may have contributed to this factor but the available evidence does not allow a robust identification. Possible contributors hypothesized in other studies of Arctic carboxylic acids are discussed below including biomass burning, atmospheric or snow photochemical processing, and ocean microlayer emissions. However, some studies have postulated the existence of a yet unidentified source of high-latitude carboxylic acids (e.g., Paulot et al., 2011) which may be reflected in Factor 4. A similar high carboxylic acid factor was resolved for runs with six or more factors and maintained its composition with Pearson's correlation coefficients of over 0.96; however, the loading of $\mathrm{BC}$ and $\mathrm{K}^{+}$onto this carboxylic acid factor was much more variable over the additional runs.

Carboxylic acids within the Arctic have previously been linked with biomass burning plumes (e.g., Jaffrezo et al., 1998; Legrand and de Angelis, 1996). The mass ratio of $\mathrm{BC}$ and $\mathrm{K}^{+}$apportioned to this factor was similar to that of a biomass burning plume, particularly the high $\mathrm{K}^{+}$proportion typical of herbaceous burning (Turn et al., 1997; Saarikoski et al., 2007; McMeeking et al., 2009; May et al., 2014). However, both $\mathrm{BC}$ and $\mathrm{K}^{+}$loading showed significant uncertainty. The loadings of formate, acetate, $\mathrm{Cl}^{-}, \mathrm{Br}^{-}$, $\mathrm{C}_{2} \mathrm{O}_{4}^{2-}$, and $\mathrm{NH}_{4}^{+}$appeared to be higher than expected for biomass burning emissions; the mass ratio of these analytes to $\mathrm{BC}$ were enriched by a factor of 3 to 75 relative to typical mass ratios of biomass burning emissions, based on a review of measured herbaceous and woody emissions (Turn et al., 1997; Andreae and Merlet, 2001; Hays et al., 2005; Saarikoski et al., 2007; McMeeking et al., 2009; May et al., 2014). The observed enrichment ratios of this factor above typical biomass burning plumes could be explained by atmospheric processing, for example, the cloud processing suggested by Legrand and de Angelis (1995). Alternatively, gasphase partitioning and the subsequently enhanced scavenging observed in a previous study of these data (Macdonald et al., 2017) may have led to increased levels of some coemitted chemical species relative to BC. The fall and spring peak of Factor 4 may support a biomass burning identification, as burning events are more typical in warmer seasons, specifically a North American source as suggested by the FLEXPART analysis.

Previous studies have also suggested a photochemical processing source of these carboxylic acids in the Arctic. Dibb and Arsenault (2002) found elevated levels of formic and acetic acid in the pore space of deposited Arctic snow and hypothesized oxidation of carbonyls and alkenes within the snowpack as a likely source. The prevalence of the factor in the fall and spring, before polar sunset and after polar sunrise, would support a photochemical source. Furthermore, summertime measurements of Arctic atmospheric samples by Mungall et al. (2017) also showed high levels of formic and acetic acid and hypothesized an oceanic microlayer photochemical source. Again, the temporal trend of Factor 4 as well as the Atlantic Ocean source location would support this possibility. An atmospheric budget analysis by Paulot et al. (2011) identified a significant missing source of highlatitude formic and acetic acid. Factor 4 of this study could represent a combination of the suggested sources above or a missing source which is as yet unidentified.

\subsubsection{Factor 5: nitrate}

The fifth factor was characterized by high $\mathrm{NO}_{3}^{-}, 86 \% \mathrm{~m} / \mathrm{m}$ loading (Fig. 1). This factor was also seen to have moderate loadings of MS and $\mathrm{Br}^{-}, 20-30 \%$, but with a larger degree of uncertainty. The atmospheric chemistry of $\mathrm{NO}_{3}^{-}$is complex, involving a variety of sources, formation mechanisms, and destruction mechanisms; in particular, snow can act as both a sink and a source of atmospheric nitrogen oxides, further complicating the local $\mathrm{NO}_{3}^{-}$cycle (Beine et al., 2002; Ianniello et al., 2002; Morin et al., 2008; Fibiger et al., 2016). Furthermore, the complex processing of $\mathrm{NO}_{3}^{-}$ was demonstrated in the earlier deposition analysis of these data which suggested that gas-phase deposition was a dominant mechanism of $\mathrm{NO}_{3}^{-}$transport to snow (Macdonald et al., 2017). Thus, the loading of $\mathrm{NO}_{3}^{-}$onto a separate factor may be a reflection of its unique atmospheric processing. Comparison of simultaneous snow and atmospheric measurements over this campaign, as described in Macdonald et 
al. (2017), showed $\mathrm{NO}_{3}^{-}$to have a higher effective deposition velocity than $\mathrm{BC}$ or $\mathrm{SO}_{4}^{2-}$. This supports external mixing of these compounds in the atmosphere and thus their assignment to separate source factors. This $\mathrm{NO}_{3}^{-}$-loaded factor was resolved for simulations with six or more factors, prior to which this factor appears to be combined with the carboxylic acid factor. In addition, a similar unique $\mathrm{NO}_{3}^{-}$factor was also observed in previous snow and atmospheric apportionment studies (Sirois and Barrie, 1999; Hegg et al., 2009, 2010).

Factor 5 showed a variable contribution throughout the campaign but especially elevated in December. This factor was not found to correlate significantly with any nonapportioned analyte or meteorological parameter; however, Factor 5 did weakly correlate with nitrite $\left(\mathrm{NO}_{2}^{-}\right)$and $\mathrm{H}^{+}$ with Pearson's correlation coefficients of 0.35 and 0.46 , respectively. This correlation with $\mathrm{H}^{+}$is in agreement with this factor's low neutralization ratio of 0.04 . The low fall/spring levels of this factor may reflect the loss of $\mathrm{NO}_{3}^{-}$from snow through photolysis driven by the sunlight availability after polar sunrise (Morin et al., 2008; Fibiger et al., 2016). The highest $\mathrm{NO}_{3}^{-}$levels were observed when photolysis was inhibited during the polar sunset from mid-October to late February. The movement of $\mathrm{NO}_{3}^{-}$accumulated in the snow to atmosphere during the spring is supported by the broad peak in atmospheric $\mathrm{NO}_{3}^{-}$observed via $\mathrm{Hi}-\mathrm{Vol}$ filters from February to the end of the atmospheric sampling in mid-May. February to June 2015 was also characterized by a "bromide explosion", observed as a broad peak in snow and atmospheric $\mathrm{Br}^{-}$(Macdonald et al., 2017). It is possible that this offered a different formation pathway for $\mathrm{NO}_{3}^{-}$over this period via the reaction of $\mathrm{NO}_{2}$ and $\mathrm{BrO}$ (Morin et al., 2008). The mid-winter peak in this factor may be linked to $\mathrm{NO}_{3}^{-}$ formation via $\mathrm{N}_{2} \mathrm{O}_{5}$ hydrolysis in the aerosol phase, which is considered to dominate Arctic $\mathrm{NO}_{3}^{-}$chemistry during the night (Morin et al., 2008).

Potential source areas of this factor, largely driven by the December peak, are shown in Fig. 3. This plot was found to be similar to that of Factor 3, primarily northern Eurasia, though with a possible stronger dependence on northern $\mathrm{Eu}-$ rope. Thus, the $\mathrm{NO}_{3}^{-}$precursors to this factor may be largely anthropogenic in origin. Additionally, this factor appears to coincide with increased transport over the ice-free open water. This transport pathway might explain the presence of MS, typically considered an indicator of marine biogenic activity within warmer ice-free water bodies ( $\mathrm{Li}$ et al., 1993; Ye et al., 2015).

\subsubsection{Factor 6: non-crustal metals}

Factor 6 showed a high loading of $\mathrm{Sb}, \mathrm{Pb}$, and $\mathrm{As}, 40$ $60 \% \mathrm{~m} / \mathrm{m}$, and moderate $\mathrm{Cu}$ loading, $28 \%$, as shown in Fig. 1. These metals are frequently associated with industrial emissions, particularly high-temperature activities such as fossil fuel combustion and smelting (Berg et al., 1994; Laing et al., 2014). Although total Se and V loadings to this factor are low, the non-crustal loading of these metals (i.e., percentage of total excluding that which is loaded on Factor 2) is $20-30 \%$. This factor also contains $10 \%$ of non-sea salt $\mathrm{SO}_{4}^{2-}$. These constituents also point towards an industrial source (Berg et al., 1994; Laing et al., 2014). A neutralization ratio of 0.37 for this factor suggested an acidic aerosol. Factor 6 exhibited major peaks in October, December, and March and was found to be associated with a Eurasian source (Figs. 2 and 3). Although several of the non-apportioned metals had limited measurements above MDL, a possible correlation was observed between Factor 6 and insoluble Ti, Cr, and $\mathrm{Tl}$, and soluble $\mathrm{As}, \mathrm{Pb}, \mathrm{Cr}$, and $\mathrm{Cd}$. These metals are often considered to be primarily industrial in origin (Berg et al., 1994; Laing et al., 2014). The similarity in the FLEXPART potential source maps between Factor 3 BC and Factor 6 may support their mutual designation as anthropogenic related.

Factors 6 and 7 were resolved separately only for solutions with seven or more factors. With the addition of a ninth factor, the non-crustal metals factor was further split into a factor dominated by $\mathrm{As}$ and $\mathrm{Pb}$ and a second factor dominated by $\mathrm{Sb}$. This may represent the resolution of different industrial sources; however, the addition of these factors was not found to greatly improve the overall solution fit. Factors dominated by non-crustal metals, specifically $\mathrm{Pb}$ and $\mathrm{As}$, have been observed in previous atmospheric apportionment studies (Sirois and Barrie, 1999; Nguyen et al., 2013) but not as clearly in existing snow apportionment studies (Hegg et al., 2009, 2010).

\subsubsection{Factor 7: sulfate}

Factor 7 was characterized by $\mathrm{SO}_{4}^{2-}$ and MS, with loadings of 68 and $42 \% \mathrm{~m} / \mathrm{m}$, respectively (Fig. 1). MS is considered to be a tracer for biogenic marine activity; however, the mass ratio of $\mathrm{MS} / \mathrm{SO}_{4}^{2-}$ observed in Factor 7, 0.003, is far below that typically seen for marine biogenic emissions, 0.05-0.20 ( $\mathrm{Li}$ et al., 1993). The portion of $\mathrm{SO}_{4}^{2-}$ in this factor related to marine biogenic emissions was estimated at about $2-7 \%$, assuming a typical $\mathrm{MS}$ / marine- $\mathrm{SO}_{4}^{2-}$ mass ratio and similar scavenging of MS and marine $\mathrm{SO}_{4}^{2-}$. Thus, an additional source of $\mathrm{SO}_{4}^{2-}$ to this factor was suggested. Sulfate is typically an indicator of anthropogenic activities; however, the potential source regions identified for Factor 7 in Fig. 3 are largely confined to the Arctic where anthropogenic sources are minimal. The source region identified is only a 10-day back trajectory, so it is possible that the area of influence would extend farther south if longer trajectories were considered. However, given that $91 \%$ of the 10-day FLEXPART area is within $65^{\circ} \mathrm{N}$, a northern and likely natural source seems likely. Furthermore, $\mathrm{BC}$ and $\mathrm{NO}_{3}^{-}$, typical indicators of industrial activity, both showed low loadings $(<6 \% \mathrm{~m} / \mathrm{m})$ onto Factor 7, again suggesting this factor is not anthropogenic in origin. The loading of $\mathrm{SO}_{4}^{2-}$ onto Factor $3 \mathrm{BC}$ and Factor 6 non-crustal metals is more consistent with anthropogenic sources. 
Aside from anthropogenic and marine sources, volcanic activity can be a significant source of atmospheric $\mathrm{SO}_{4}^{2-}$. Volcanic emissions are characterized by high levels of sulfur dioxide $\left(\mathrm{SO}_{2}\right.$, an oxidation precursor of $\left.\mathrm{SO}_{4}^{2-}\right)$, acidic compounds, and a variety of metals (AMAP, 2006). A volcanic source would be consistent with the observed low levels of $\mathrm{BC}$ and $\mathrm{NO}_{3}^{-}$associated with Factor 7. Significant loadings of non-crustal Se and V $(62$ and $28 \% \mathrm{~m} / \mathrm{m}$, respectively), correlation with $\mathrm{H}^{+}$and $\mathrm{Ba}$, and an acidic neutralization ratio also support a potential volcanic source for Factor 7 (Key and Hoggan, 1953; Rahn, 1971; Berg et al., 1994; AMAP, 2006; Laing et al., 2014). Several volcanoes within the near Arctic were known to be active over the 20142015 season: Bárðarbunga, Iceland; Shishaldin, Aleutian Islands; Sheveluch, Bezymianny, and Zhupanovsky, Kamchatka Peninsula; and Chirpoi, Kuril Islands (Global Volcanism Program, retrieved March 2016 from http://volcano.si. edu/). The Smoking Hills, naturally combusting coal and oil shale deposits on the northern coast of the Northwest Territories, Canada, at Cape Bathurst, $69.5^{\circ} \mathrm{N}, 126.2^{\circ} \mathrm{W}$, are also located near the identified source region of Factor 7 (Freedman et al., 1990; AMAP, 2006); however, it is expected that the contribution from these hill would be minimal. Factor 7 showed a distinct maximum in September-October and a low contribution throughout the remainder of the campaign. This corresponds with volcanic activity at the Bárðarbunga volcano in Iceland as observed by others (Icelandic Met Office via Global Volcanism Program, retrieved March 2016 from http://volcano.si.edu/). Comparison of these snow measurements to previous seasonal snow measurement campaigns (e.g., Davidson et al., 1993; Toom-Sauntry and Barrie, 2002) showed this fall peak in $\mathrm{SO}_{4}^{2-}$ snow concentration and flux to be unusual. This further supports a non-seasonal event such as a volcanic eruption as a major contributor to Factor 7, sulfate. These volcanic sources are shown on the source region plot for Factor 7 sulfate as well as the smoking hills for context (Fig. 3). Although none of these locations appear to have high associated residence times within the 10-day back trajectory analysis, they appear closer to the identified source regions than major industrial activities farther south. Given the heat and velocity of a volcanic emission, the near-surface restriction applied to the FLEXPART trajectories to identify likely source regions may not be appropriate for Factor 7. Supplement Sect. S2.2 provides potential source/influence region plots for peak fall periods associated with Factor 7 for a larger range of source altitudes: 0 to $10 \mathrm{~km}$ above ground level. These plots do show potential influence from Bárðarbunga in Iceland.

The coincident enhancement of MS production within the ice-free biogenically active Arctic Ocean in the fall would explain why MS was also found to be loaded onto this factor. Photochemical $\mathrm{SO}_{4}^{2-}$ apportionment sources have been observed in some previous apportionment studies, though not as commonly as other factors (e.g., Sirois and Barrie, 1999). Significant volcanic influences on Arctic aerosol have also been noted by previous apportionment studies (VanCuren et al., 2012).

Previous analysis of snow and atmospheric samples over this campaign (Macdonald et al., 2017) found $\mathrm{SO}_{4}^{2-}$ to exhibit an enhanced deposition velocity relative to $\mathrm{BC}$, especially during the warm fall months. Typical internally mixed anthropogenic particulate $\mathrm{SO}_{4}^{2-}$ and $\mathrm{BC}$ would be expected to exhibit similar deposition velocities; thus, this discrepancy supported a distinct fall source of $\mathrm{SO}_{4}^{2-}$ which was more readily scavenged and deposited than $\mathrm{BC}$. It is possible that heightened scavenging of volcanic $\mathrm{SO}_{2}$ emissions in the warmer fall resulted in this seasonal trend and the identification of a separate non-anthropogenic $\mathrm{SO}_{4}^{2-}$ factor.

Within a six-factor solution, Factor 6 and 7 were essentially combined into a single factor. This combined factor did not exhibit a clear distinct source region, nor was it easily interpretable. The six-factor solution also did not predict the observed distinct fall peak in $\mathrm{SO}_{4}^{2-}$ (as shown in Supplement Fig. S7). Thus, the use of a seven-factor solution vastly improved $\mathrm{SO}_{4}^{2-}$ apportionment for this campaign.

\subsection{Overall apportionment}

Considering Fig. 3 and Table 2, the apportioned factors can be split into two groups by potential influence and/or source regions: those dominated by anthropogenic sources and those by natural sources. All factors showed a significant influence from Arctic regions since all trajectories were initialized at Alert, but three factors showed heightened influence from areas outside of the Arctic: Factor 3 black carbon, Factor 5 nitrate, and Factor 6 non-crustal metals. All three were observed to have potential areas of influence extending south into Eurasia, up to and below $45^{\circ} \mathrm{N}$. Although each factor is potentially an amalgamation of several co-emitted or coaligned sources, per the discussion above, the composition and peak periods of Factor 3, BC, and Factor 6, non-crustal metals, suggest they are primarily anthropogenic in origin. While Factor 5 appears to represent the distinct $\mathrm{NO}_{3}^{-}$atmospheric chemistry, the precursors to these reactions may also be anthropogenic in origin. Factor 1, sea salt, also showed a large influence area within northern Eurasia (per Table 2); however, it is believed that this represents influence from the coast during ice-free periods. Thus, Factor 1 sea salt, Factor 2 crustal metals, Factor 4 carboxylic acids, and Factor 7 sulfate all appear to be dominated by influences and/or sources north of $65^{\circ} \mathrm{N}$. Per the discussion above, these factors all appear to have largely natural sources, although additional evidence on the identity of Factor 4 and 7 in particular is warranted. Based on these identifications the rough proportion of each analyte apportioned to factors which most closely resemble anthropogenic sources (Factor $3 \mathrm{BC}$, Factor 5 nitrate, and Factor 6 non-crustal metals) or natural sources (Factor 1 sea salt, Factor 2 crustal, Factor 4 carboxylic acid, and Factor 7 sulfate) can be estimated. Table 3 provides a summary of this classification. 
Table 3. Overview of analyte apportionment.

\begin{tabular}{|c|c|c|c|c|c|c|c|c|c|c|c|}
\hline \multirow[t]{2}{*}{ Factor } & \multirow{2}{*}{$\begin{array}{r}1 \\
\text { Sea } \\
\text { salt }\end{array}$} & \multirow{2}{*}{$\begin{array}{r}2 \\
\begin{array}{r}\text { Crustal } \\
\text { metals }\end{array}\end{array}$} & \multirow{2}{*}{$\begin{array}{r}3 \\
\mathrm{BC}\end{array}$} & 4 & 5 & 6 & 7 & \multicolumn{4}{|c|}{$\begin{array}{l}\text { Total loading by most closely } \\
\text { resembled source type }\end{array}$} \\
\hline & & & & $\begin{array}{r}\text { Carboxylic } \\
\text { acids }\end{array}$ & Nitrate & $\begin{array}{r}\text { Non-crustal } \\
\text { metals }\end{array}$ & Sulfate & $\begin{array}{r}\text { Primar } \\
(\mathrm{Fa}\end{array}$ & $\begin{array}{l}\text { thropogenic } \\
\left.3,5^{*}, 6\right)\end{array}$ & $\begin{array}{l}\text { Prim } \\
\text { (Facto }\end{array}$ & $\begin{array}{l}\text { rrily natural } \\
\left.1,2,4^{*}, 7^{*}\right)\end{array}$ \\
\hline Analyte & Loadil & $\mathrm{g}$ (mass / & hass) & & & & & & & & \\
\hline $\mathrm{BC}$ & $5 \%$ & $0 \%$ & $66 \%$ & $17 \%$ & $0 \%$ & $8 \%$ & $5 \%$ & $73 \%$ & [60-124\%] & $27 \%$ & [3-67\%] \\
\hline MS & $5 \%$ & $0 \%$ & $10 \%$ & $12 \%$ & $27 \%$ & $4 \%$ & $42 \%$ & $41 \%$ & {$[6-128 \%]$} & $59 \%$ & [26-176\%] \\
\hline ACE & $0 \%$ & $5 \%$ & $10 \%$ & $79 \%$ & $0 \%$ & $0 \%$ & $6 \%$ & $10 \%$ & [8-75\%] & $90 \%$ & [51-155\%] \\
\hline FOR & $0 \%$ & $10 \%$ & $0 \%$ & $80 \%$ & $1 \%$ & $8 \%$ & $0 \%$ & $9 \%$ & [3-69\%] & $91 \%$ & {$[50-151 \%]$} \\
\hline $\mathrm{Cl}^{-}$ & $79 \%$ & $3 \%$ & $7 \%$ & $2 \%$ & $2 \%$ & $2 \%$ & $5 \%$ & $11 \%$ & [7-40\%] & $89 \%$ & [69-110\%] \\
\hline $\mathrm{Br}^{-}$ & $34 \%$ & $0 \%$ & $0 \%$ & $26 \%$ & $23 \%$ & $15 \%$ & $4 \%$ & $37 \%$ & [2-108\%] & $63 \%$ & [30-138\%] \\
\hline $\mathrm{NO}_{3}^{-}$ & $0 \%$ & $10 \%$ & $4 \%$ & $0 \%$ & $86 \%$ & $0 \%$ & $0 \%$ & $90 \%$ & [64-111\%] & $10 \%$ & [4-58\%] \\
\hline $\mathrm{SO}_{4}^{2-}$ & $10 \%$ & $4 \%$ & $5 \%$ & $0 \%$ & $4 \%$ & $9 \%$ & $68 \%$ & $18 \%$ & {$[14-76 \%]$} & $82 \%$ & {$[62-141 \%]$} \\
\hline $\mathrm{C}_{2} \mathrm{O}_{4}^{2-}$ & $27 \%$ & $8 \%$ & $9 \%$ & $8 \%$ & $14 \%$ & $22 \%$ & $12 \%$ & $45 \%$ & [27-83\%] & $55 \%$ & [30-116\%] \\
\hline $\mathrm{Na}^{+}{ }^{4}$ & $79 \%$ & $4 \%$ & $0 \%$ & $2 \%$ & $0 \%$ & $7 \%$ & $9 \%$ & $7 \%$ & [4-41\%] & $93 \%$ & [73-118\%] \\
\hline $\mathrm{NH}_{4}^{+}$ & $15 \%$ & $2 \%$ & $17 \%$ & $47 \%$ & $5 \%$ & $5 \%$ & $8 \%$ & $28 \%$ & [25-80\%] & $72 \%$ & [41-111\%] \\
\hline $\mathrm{K}^{+}{ }^{4}$ & $38 \%$ & $10 \%$ & $0 \%$ & $4 \%$ & $20 \%$ & $10 \%$ & $19 \%$ & $29 \%$ & [8-93\%] & $71 \%$ & [36-143\%] \\
\hline $\mathrm{Mg}^{2+}$ & $43 \%$ & $34 \%$ & $1 \%$ & $5 \%$ & $0 \%$ & $0 \%$ & $17 \%$ & $1 \%$ & [1-37\%] & $99 \%$ & {$[76-126 \%]$} \\
\hline $\mathrm{Al}$ & $2 \%$ & $84 \%$ & $0 \%$ & $0 \%$ & $3 \%$ & $3 \%$ & $7 \%$ & $7 \%$ & [2-43\%] & $93 \%$ & {$[70-136 \%]$} \\
\hline $\mathrm{V}$ & $2 \%$ & $84 \%$ & $1 \%$ & $1 \%$ & $3 \%$ & $5 \%$ & $5 \%$ & $9 \%$ & [3-47\%] & $91 \%$ & [68-130\%] \\
\hline $\mathrm{Cu}$ & $6 \%$ & $48 \%$ & $0 \%$ & $0 \%$ & $7 \%$ & $28 \%$ & $11 \%$ & $35 \%$ & [19-82\%] & $65 \%$ & {$[32-143 \%]$} \\
\hline As & $5 \%$ & $44 \%$ & $7 \%$ & $0 \%$ & $0 \%$ & $44 \%$ & $0 \%$ & $52 \%$ & [15-109\%] & $48 \%$ & [38-106\%] \\
\hline $\mathrm{Se}$ & $0 \%$ & $81 \%$ & $2 \%$ & $1 \%$ & $0 \%$ & $3 \%$ & $12 \%$ & $6 \%$ & [2-44\%] & $94 \%$ & [69-141\%] \\
\hline $\mathrm{Sb}$ & $0 \%$ & $0 \%$ & $4 \%$ & $18 \%$ & $1 \%$ & $60 \%$ & $17 \%$ & $64 \%$ & [42-126\%] & $36 \%$ & {$[11-99 \%]$} \\
\hline $\mathrm{Pb}$ & $4 \%$ & $25 \%$ & $8 \%$ & $8 \%$ & $0 \%$ & $53 \%$ & $2 \%$ & $61 \%$ & [35-95\%] & $39 \%$ & [27-108\%] \\
\hline
\end{tabular}

Table 3 indicates that $\mathrm{NO}_{3}^{-}, \mathrm{BC}, \mathrm{Sb}$, and $\mathrm{Pb}$ are likely all dominated by anthropogenic sources. In contrast, $\mathrm{Mg}^{2+}, \mathrm{Se}$, $\mathrm{Al}, \mathrm{Na}^{+}, \mathrm{V}$, formate, acetate, $\mathrm{Cl}^{-}, \mathrm{SO}_{4}^{2-}, \mathrm{NH}_{4}^{+}$, and $\mathrm{K}^{+}$are all likely dominated by natural sources. The total apportionment of As, $\mathrm{C}_{2} \mathrm{O}_{4}^{2-}$, MS, Br-, and $\mathrm{Cu}$ to anthropogenic and natural-resembling factors was found to be uncertain based on the bootstrapping analysis. Most notable in this analysis was the apportionment of $\mathrm{BC}, \mathrm{SO}_{4}^{2-}, \mathrm{V}$, and Se. While the loading of $\mathrm{BC}$ is known to vary between anthropogenic and natural sources by location and season, typically $\mathrm{SO}_{4}^{2-}, \mathrm{V}$, and Se would be expected to be primarily anthropogenic in origin. Figure 4 summarizes the apportionment of $\mathrm{BC}, \mathrm{SO}_{4}^{2-}$, and $\mathrm{V}$ over the campaign. The apportionment of Se was similar to that of $\mathrm{V}$.

As discussed above, Arctic BC is often considered to be primarily anthropogenic in origin over the winter season; however, there is some contradictory evidence. It would appear that the sources of BC to Arctic snow vary by location, season, and year. Figure 4 shows that snow BC in this study was dominated by Factor 3, believed to be predominantly anthropogenic in origin. Only about $17 \%$ of BC was loaded onto the factor most resembling biomass burning, Factor 4 carboxylic acid, similar to the findings of previous modelling and composition-based apportionment estimates for particulate matter (Slater et al., 2002; Flanner et al., 2007; Skeie et al., 2011; Wang et al., 2011; Yttri et al., 2011, 2014). The dominant factor for BC varied over the campaign: Factor 3, BC, was dominant from November through April, but Factor 4, carboxylic acids, and Factor 7, sulfate, showed larger contributions in the fall and spring. However, given the low levels of BC observed over fall and spring, the absolute contributions of Factor 4 and 7 were small and susceptible to significant uncertainty. The portions of BC assigned to Factor 1 sea salt and Factor 2 crustal metals likely represent a regional background level of $\mathrm{BC}$ and therefore are likely the combined product of both anthropogenic and natural emissions.

The $\mathrm{SO}_{4}^{2-}$ signal was dominated by a fall peak primarily loaded onto Factor 7. While additional evidence is required to corroborate the identity of this factor, the coincidental eruption of Bárðarbunga in Iceland may suggest a significant volcanic source during the fall of this campaign. The absolute flux of $\mathrm{SO}_{4}^{2-}$ in the winter and spring was relatively small compared to the fall peak and mostly comprised of Factor 1 sea salt and Factor 7 sulfate. However, episodic peaks in Factor 3 BC and Factor 6 non-crustal metals suggest influence from anthropogenic plumes. Excluding the SeptemberOctober peak, the $\mathrm{SO}_{4}^{2-}$ loading is approximately $39 \%$ anthropogenic ( $12 \%$ Factor 3 BC, $9 \%$ Factor 5 nitrate, and $18 \%$ Factor 6 non-crustal metals) and $61 \%$ natural $(23 \%$ 


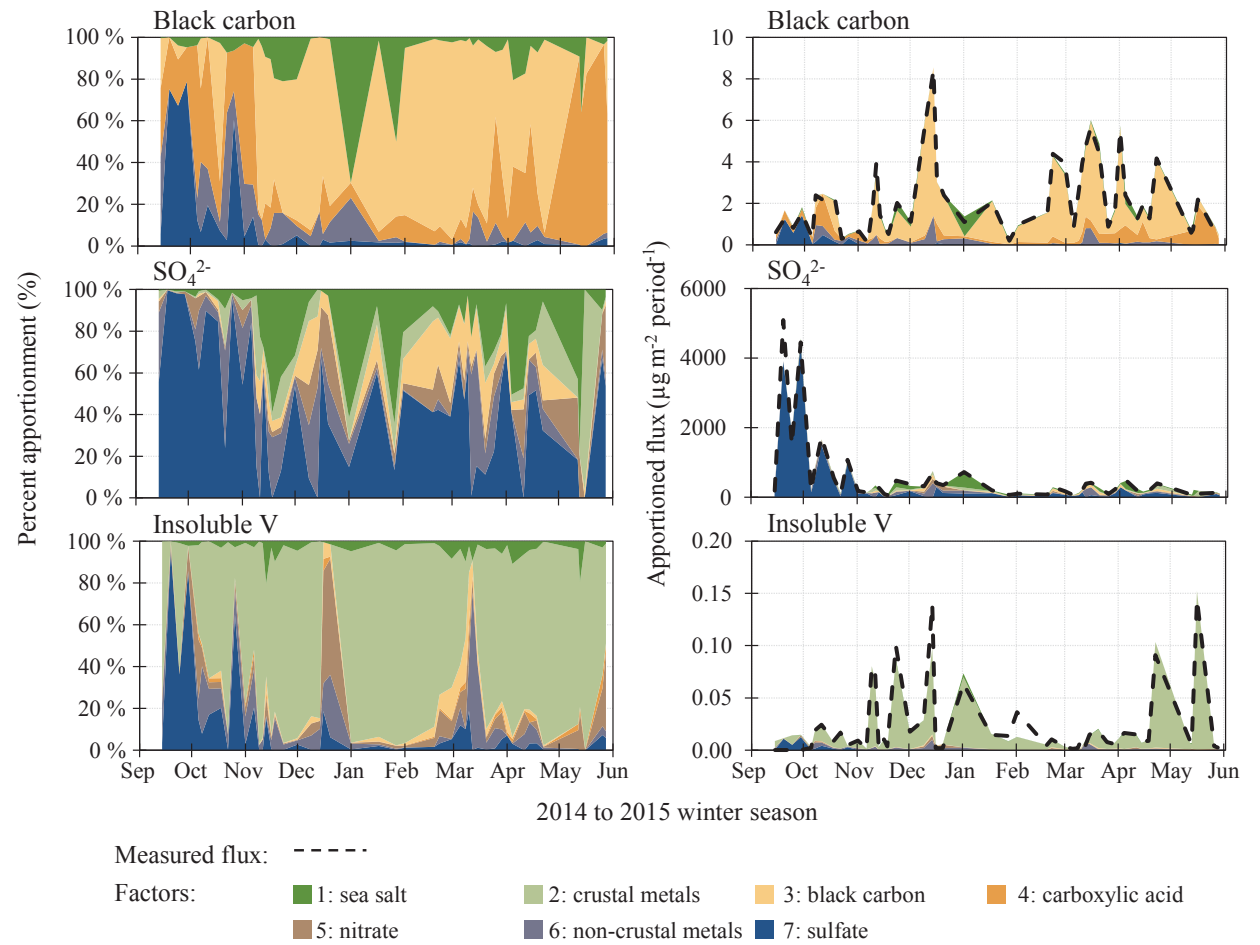

Figure 4. Percent and total apportionment of $\mathrm{BC}, \mathrm{SO}_{4}^{2-}$, and $\mathrm{V}$ in snow over the 2014-2015 campaign.

Factor 1 sea salt, $10 \%$ Factor 2 crustal metals, $0 \%$ Factor 4 carboxylic acid, and $28 \%$ Factor 7 sulfate). Thus, factors considered anthropogenic account for about $50 \%$ of the nonsea salt $\mathrm{SO}_{4}^{2-}$ signal over this period. If Factor 7 were missidentified as natural, then approximately $67 \%$ of $\mathrm{SO}_{4}^{2-}$ or $87 \%$ of non-sea salt $\mathrm{SO}_{4}^{2-}$ over the winter-spring would be considered likely anthropogenic in origin.

Both V and Se are typically considered to be tracers of anthropogenic activity, specifically oil and coal combustion (Key and Hoggan, 1953; Rahn, 1971; Berg et al., 1994; Laing et al., 2014). However, the dominant source of $\mathrm{V}$ and $\mathrm{Se}$ observed in this study was soil in Factor 2 crustal metals. The loading of these metals relative to Al appeared consistent with the range previously observed by others in soils; also, the raw concentration measurements of these metals showed high correlation with Al. Thus, the apportionment of these metals to primarily natural sources is considered reasonable. As shown in Fig. 4, V shows episodic peaks in Factor 5 nitrate, Factor 6 non-crustal metals, and Factor 7 sulfate. Both Factor 5 and 6 are believed to be predominantly anthropogenic in origin; thus, these peaks may represent episodic plumes from oil- and coal-burning activities. However, as shown in Table 3, the total loadings of $\mathrm{V}$ and Se to these factors are low.

In general, the apportioned analytes differed in how exclusively they were attributed. Some analytes were found to be predominantly loaded onto a single factor: BC, sea salt, and crustal metals. This may indicate that much of the mass of these analytes exists in externally mixed particles or internally mixed with a relatively small coating mass. In contrast, other analytes were found to be loaded more evenly onto several factors: $\mathrm{MS}, \mathrm{Br}^{-}, \mathrm{K}^{+}$, and $\mathrm{C}_{2} \mathrm{O}_{4}^{2-}$. Thus, these analytes may exist primarily as internally mixed particles or gas-phase compounds. This assessment is in agreement with previous explorations in the deposition characteristics of these data (Macdonald et al., 2017).

\section{Conclusions}

The Arctic climate has undergone significant climate change over recent decades and any effort to control and mitigate these changes requires improved understanding of the source contributing to the Arctic snow burden. The data presented here represent an unprecedented campaign of temporally refined and broadly speciated snow samples which is the first of its kind to be applied to a detail source apportionment analysis. Positive matrix factorization of the snow measurements was found to resolve seven factors with good solution diagnostics, interpretability, and agreement with measured values. These factors were identified based on composition, seasonal contribution, and FLEXPART-predicted major source regions: sea salt, crustal metals, black carbon, carboxylic acids, nitrate, non-crustal metals, and sulfate. Based on possible factor identification, BC apportionment was found to load $73 \% \mathrm{~m} / \mathrm{m}$ of the total flux onto factors considered to be 
primarily anthropogenic in origin; however, the lower levels of $\mathrm{BC}$ in the fall and spring were largely associated with factors which might be associated with North American biomass burning. These BC apportionment results reiterate the importance in understanding the variation in $\mathrm{BC}$ sources by year, location and season. In contrast, $\mathrm{SO}_{4}^{2-}, \mathrm{V}$, and Se were only attributed to factors resembling anthropogenic sources by 18 , 9 , and $6 \% \mathrm{~m} / \mathrm{m}$, respectively. The $\mathrm{SO}_{4}^{2-}$ signal was dominated by a fall peak with limited $\mathrm{BC}$ loading. Based on the coincidental eruption of a volcano in Iceland and the lack of anthropogenic tracers, this peak was believed to be predominantly natural in origin. This result may indicate the importance of high volcanic activity years. The low anthropogenic $\mathrm{V}$ signal was due to significant loading of $\mathrm{V}$ onto a crustal source. The mass ratios of $\mathrm{V}$ and Se relative to $\mathrm{Al}$ in this factor were fairly consistent with the typical range seen in soils; furthermore, the raw measurements of both metals showed high correlation with $\mathrm{Al}$. The anthropogenic signal of $\mathrm{V}$ and Se was largely attributed to a factor dominated by non-crustal metals which was believed to represent mixed Eurasian anthropogenic emissions. Comparison of these results to a previous analysis of the deposition characteristics of these data highlighted the importance of relative deposition velocity and mixing state in the apportionment of analytes in snow. Future analyses of Arctic snow would be required to fully understand these complexities.

Data availability. This data will be made public as part of an ECCC archive for the NETCARE project. Until that time data can be requested from the corresponding author.

\section{The Supplement related to this article is available online at https://doi.org/10.5194/acp-18-3485-2018-supplement.}

Author contributions. Organization of the snow collection campaign was led by SS with the assistance of AP and collection by ME. Snow analyses were completed by JM, NC, DT, LH, and KM with the assistance of AC, YL, and CHJ. Ambient atmospheric monitoring was completed by DT and RL. FLEXPART simulations were completed by HB and DK with data analysis assisted by KM. PMF analysis was completed by $\mathrm{KM}$ with input on interpretation from all authors. GE and JA provided oversight for the project, including input on the manuscript.

Competing interests. The authors declare that they have no conflict of interest.

Special issue statement. This article is part of the special issue "NETCARE (Network on Aerosols and Climate: Addressing Key Uncertainties in Remote Canadian Environments) (ACP/AMT/BG inter-journal SI)". It is not associated with a conference.
Acknowledgements. Funding of this study was provided as part of the Network on Climate and Aerosols Research (NETCARE), Natural Science and Engineering Research Council of Canada (NSERC), the government of Ontario through the Ontario Graduate Scholarship (OGS), and Environment and Climate Change Canada. This project would not have been possible without the collaboration of many skilled individuals, including Allan K. Bertram and Sarah Hanna at the University of British Columbia and Catherine Philips-Smith at the University of Toronto.

Edited by: Lynn M. Russell

Reviewed by: three anonymous referees

\section{References}

AMAP: Acidifying pollutants, Arctic haze, and acidification in the Arctic, Arctic Monitoring and Assessment Programme, Oslo, Norway, 2006.

AMAP: Black carbon and ozone as Arctic climate forcers, Arctic Monitoring and Assessment Programme, Oslo, Norway, 2015.

AMAP: Snow, water, ice and permafrost in the Arctic (SWIPA), Arctic Monitoring and Assessment Programme, Oslo, Norway, 2017.

Andreae, M. O. and Merlet. P.: Emission of trace gases and aerosols from biomass burning, Global Biogeochem. Cy., 15, 955-966, https://doi.org/10.1029/2000GB001382, 2001.

Barrett, T. E., Robinson, E. M., Usenko, S., and Sheesley, R. J.: Source contributions to wintertime elemental and organic carbon in the western Arctic based on radiocarbon and tracer apportionment, Environ. Sci. Technol., 49, 11631-11639, https://doi.org/10.1021/acs.est.5b03081, 2015.

Barrie, L. A.: Arctic air pollution: An overview of current knowledge, Atmos. Environ., 20, 643-663, https://doi.org/10.1016/0004-6981(86)90180-0, 1986.

Barrie, L. A., Hoff, R. M., and Daggupaty, S. M.: The Influence of mid-latitudinal pollution sources on haze in the Canadian Arctic, Atmos. Environ., 15, 1407-1419, https://doi.org/10.1016/00046981(81)90347-4, 1981.

Barrie, L. A., den Hartog, G., and Bottenheim, J. W.: Anthropogenic aerosols and gases in the lower troposphere at Alert, J. Atmos. Chem., 9, 101-127, https://doi.org/10.1007/BF00052827, 1989.

Behera, S. N., Sharma, M., Aneja, V. P., and Balasubramanian, R.: Ammonia in the atmosphere: A Review on emission sources, atmospheric chemistry and deposition on terrestrial bodies, Environ. Sci. Pollut. R., 20, 8092-8131, https://doi.org/10.1007/s11356-013-2051-9, 2013.

Beine, H. J., Honrath, R. E., Domine, F., and Simpson, W. R.: NOx during background and ozone depletion periods at Alert: Fluxes above the snow surface, J. Geophys. Res., 107, 7-1-7-12, https://doi.org/10.1029/2002JD002082, 2002.

Berg, T., Røyset, O., and Steinnes, E.: Trace elements in atmospheric precipitation at Norweigan background stations (19891990) measured by ICP-MS, Atmos. Environ., 28, 3519-3536, https://doi.org/10.1016/1352-2310(94)90009-4, 1994.

Bond, T. C., Doherty, S. J., Fahey, D. W., Forster, P. M., Berntsen, T., Deangelo, B. J., Flanner, M. G., Ghan, S., Kärcher, B., Koch, D., Kinne, S., Kondo, Y., Quinn, P. K., Sarofim, M. C., Schultz, M. G., Schulz, M., Venkataraman, C., Zhang, H., Zhang, S., Bel- 
louin, N., Guttikunda, S. K., Hopke, P. K., Jacobson, M. Z., Kaiser, J. W., Klimont, Z., Lohmann, U., Schwarz, J. P., Shindell, D. T., Storelvmo, T., Warren, S. G., and Zender, C. S.: Bounding the role of black carbon in the climate system: A Scientific assessment, J. Geophys. Res.-Atmos., 118, 5380-5552, https://doi.org/10.1002/jgrd.50171, 2013.

Breider, T. J., Mickley, L. J., Jacob, D. J., Wang, Q., Fisher, J. A., Chang, R. Y.-W., and Alexander, B.: Annual distributions and sources of Arctic aerosol components, aerosol optical depth, and aerosol absorption, J. Geophys. Res.-Atmos., 119, 4107-4124, https://doi.org/10.1002/2013JD020996, 2014.

Clarke, A. D. and Noone, K. J.: Soot in the Arctic snowpack: a cause for perturbations in radiative transfer, Atmos. Environ., 19, 2045-2053, https://doi.org/10.1016/0004-6981(85)90113-1, 1985.

Davidson, C. I., Jaffrezo, J.-L., Mosher, B. W., Dibb, J. E., Borys, R. D., Bodhaine, B. A., Rasmussen, R. A., Rasmussen, R. A., Boutron, C. F., Gorlach, U., Cachier, H., Ducret, J., Colin, J. L., Heidam, N. Z., Kemp, K., and Hillamo, R.: Chemical constituents in the air and snow at Dye 3, Greenland: I. Seasonal variations, Atmos. Environ. A, 27, 2709-2722, https://doi.org/10.1016/0960-1686(93)90304-H, 1993.

Dibb, J. E. and Arsenault, M.: Shouldn't snowpacks be sources of monocarboxylic acids?, Atmos. Environ., 36, 2513-2522, https://doi.org/10.1016/S1352-2310(02)00131-0, 2002.

Doherty, S. J., Warren, S. G., Grenfell, T. C., Clarke, A. D., and Brandt, R. E.: Light-absorbing impurities in Arctic snow, Atmos. Chem. Phys., 10, 11647-11680, https://doi.org/10.5194/acp-1011647-2010, 2010.

Dou, T., Xiao, C., Shindell, D. T., Liu, J., Eleftheriadis, K., Ming, J., and Qin, D.: The distribution of snow black carbon observed in the Arctic and compared to the GISS-PUCCINI model, Atmos. Chem. Phys., 12, 7995-8007, https://doi.org/10.5194/acp12-7995-2012, 2012.

Evans, M., Kholod, N., Kuklinski, T., Denysenko, A.,, Smith, S. J., Staniszewski, A., Hao, W. M., Liu, L., and Bond, T. C.: Black carbon emissions in Russia: A critical review, Atmos. Environ., 163, 9-21, https://doi.org/10.1016/j.atmosenv.2017.05.026 1352-2310, 2017.

Fibiger, D. L., Dibb, J. E., Chen, D., Thomas, J. L., Burkhart, J. F., Huey, L. G., and Hastings, M. G.: Analysis of nitrate in the snow and atmosphere at Summit, Greenland: Chemistry and transport, J. Geophys. Res.-Atmos., 121, 5010-5030, https://doi.org/10.1002/2014JD022297, 2016.

Flanner, M. G., Zender, C. S., Randerson, J. T., and Rasch, P. J.: Present-day climate forcing and response from black carbon in snow, J. Geophys. Res.-Atmos., 112, 1-17, https://doi.org/10.1029/2006JD008003, 2007.

Freedman, B., Zobens, V., Hutchinson, T. C., and Gizyn, W. I.: Intense, natural pollution affects Arctic tundra vegetation at the Smoking Hills, Canada, Ecology, 71, 492-503, https://doi.org/10.2307/1940303, 1990.

Hansen, J. and Nazarenko, L.: Soot climate forcing via snow and ice albedos, P. Natl. Acad. Sci. USA, 101, 423-428, https://doi.org/10.1073/pnas.2237157100, 2004.

Hartmann, D. J., Klein Tank, A. M. G., Rusticucci, M., Alexander, L. V., Brönnimann, S., Charabi, Y. A.-R., Dentener, F. J., Dlugokencky, E. J., Easterling, D. R., Kaplan, A., Soden, B. J., Thorne, P. W., Wild, M., and Zhai, P.: Observations: Atmosphere and surface, Climate change 2013: The Physical science basis, Contribution of working group I to the fifth assessment report of the Intergovernmental Panel on Climate Change, edited by: Stocker, T. F., Qin, D., Plattner, G.-K., Tignor, M., Allen, S. K., Boschung, J., Nauels, A., Xia, Y., Bex, V. and Midgley, P. M., Cambridge University Press, Cambridge and New York, NY, https://doi.org/10.1017/CBO9781107415324.008, 2013.

Hays, M. D., Fine, P. M., Geron, C. D., Kleeman, M. J., and Gullett, B. K.: Open burning of agricultural biomass: Physical and chemical properties of particle-phase emissions, Atmos. Environ., 39, 6747-6764, https://doi.org/10.1016/j.atmosenv.2005.07.072, 2005.

Hegg, D. A., Warren, S. G., Grenfell, T. C., Doherty, S. J., Larson, T. V., and Clarke, A. D.: Source attribution of black carbon in Arctic snow, Environ. Sci. Technol., 43, 4016-4021, https://doi.org/10.1021/es803623f, 2009.

Hegg, D. A., Warren, S. G., Grenfell, T. C., Doherty, S. J., and Clarke, A. D.: Sources of light-absorbing aerosol in arctic snow and their seasonal variation, Atmos. Chem. Phys., 10, 1092310938, https://doi.org/10.5194/acp-10-10923-2010, 2010.

Hirdman, D., Burkhart, J. F., Sodemann, H., Eckhardt, S., Jefferson, A., Quinn, P. K., Sharma, S., Ström, J., and Stohl, A.: Long-term trends of black carbon and sulphate aerosol in the Arctic: changes in atmospheric transport and source region emissions, Atmos. Chem. Phys., 10, 9351-9368, https://doi.org/10.5194/acp-109351-2010, 2010.

Huang, K., Fu, J. S., Prikhodko, V. Y., Storey, J. M., Romanov, A., Hodson, E. L., Cresko, J., Morozova, I., Ignatieva, Y., and Cabaniss, J.: Russian anthropogenic black carbon: Emission reconstruction and Arctic black carbon simulation, J. Geophys. Res.-Atmos., 120, 11306-11333, https://doi.org/10.1002/2015JD023358, 2015.

Hunter, J. D.: Matplotlib, Comput. Sci. Eng., 9, 90-95, https://doi.org/10.1109/MCSE.2007.55, 2007.

Ianniello, A., Beine, H. J., Sparapani, R., Di Bari, F., Allegrini, I., and Fuentes, J. D.: Denuder measurements of gas and aerosol species above Arctic snow surfaces at Alert 2000, Atmos. Environ., 36, 5299-5309, https://doi.org/10.1016/S13522310(02)00646-5, 2002.

Jaffrezo, J.-L., Davidson, C. I., Kuhns, H. D., Bergin, M. H., Hillamo, R., Maenhaut, W., Kahl, J. W., and Harris, J. M.: Biomass burning signatures in the atmosphere of central Greenland, J. Geophys. Res., 103, 31067-3108, https://doi.org/10.1029/98JD02241, 1998.

Jiao, C., Flanner, M. G., Balkanski, Y., Bauer, S. E., Bellouin, N., Berntsen, T. K., Bian, H., Carslaw, K. S., Chin, M., De Luca, N., Diehl, T., Ghan, S. J., Iversen, T., Kirkevåg, A., Koch, D., Liu, X., Mann, G. W., Penner, J. E., Pitari, G., Schulz, M., Seland, Ø., Skeie, R. B., Steenrod, S. D., Stier, P., Takemura, T., Tsigaridis, K., van Noije, T., Yun, Y., and Zhang, K.: An AeroCom assessment of black carbon in Arctic snow and sea ice, Atmos. Chem. Phys., 14, 2399-2417, https://doi.org/10.5194/acp14-2399-2014, 2014.

Key, C. W. and Hoggan, G. D.: Determination of trace elements in fuel oils, Anal. Chem., 25, 1673-1676, https://doi.org/10.1021/ac60083a027, 1953.

Krnavek, L., Simpson, W. R., Carlson, D., Domine, F., Douglas, T. A., and Sturm, M.: The chemical composition of surface snow in the Arctic: Examining marine, terrestrial, 
and atmospheric influences, Atmos. Environ., 50, 349-359, https://doi.org/10.1016/j.atmosenv.2011.11.033, 2012.

Laing, J. R., Hopke, P. K., Hopke, E. F., Husain, L., Dutkiewicz, V. A., Paatero, J., and Viisanen, Y.: Long-term particle measurements in Finnish Arctic: Part II - Trend analysis and source location identification, Atmos. Environ., 88, 285-296, https://doi.org/10.1016/j.atmosenv.2014.01.015, 2014.

Law, K. S. and Stohl, A.: Arctic air pollution: Origins and impacts, Science, 315, 1537-1540, https://doi.org/10.1126/science.1137695, 2007.

Law, K. S., Stohl, A., Quinn, P. K., Brock, C. A., Burkhart, J. F., Paris, J.-D., Ancellet, G., Singh, H. B., Roiger, A., Schlager, H. Dibb, J., Jacob, D. J., Arnold, S. R., Pelon, J., and Thomas, J. L.: Arctic air pollution: New insights from POLARCAT-IPY, B. Am. Meteorol. Soc., 95, 1873-1895, https://doi.org/10.1007/BF00138862, 2014.

Legrand, M. and De Angelis, M.: Origins and variations of light carboxylic acids in polar precipitation, J. Geophys. Res., 100, 1445-1462, https://doi.org/10.1029/94jd02614, 1995.

Legrand, M. and De Angelis, M.: Light carboxylic acids in Greenland ice: A Record of past forest fires and vegetation emissions from the boreal zone, J. Geophys. Res., 101, 4129-4145, https://doi.org/10.1029/95JD03296, 1996.

Li, S. M., Barrie, L. A., Talbot, R. W., Harriss, R. C., Davidson, C. I., and Jaffrezo, J. L.: Seasonal and geographic variations of methanesulfonic acid in the Arctic troposphere, Atmos. Environ., 27, 3011-3024, https://doi.org/10.1016/0960-1686(93)90333-T, 1993.

Liu, X., Huey, L. G., Yokelson, R. J., Selimovic, V., Simpson, I. J., Müller, M., Jimenez, J. L., Campuzano-Jost, P., Beyersdorf, A. J., Blake, D. R., Butterfield, Z., Choi, Y., Crounse, J. D., Day, D. A., Diskin, G. S., Dubey, M. K., Fortner, E.,, Hanisco, T. F., Hu, W., King, L. E., Kleinman, L., Meinardi, S., Mikoviny, T., Onasch, T. B., Palm, B. B., Peischl, J., Pollack, I. B., Ryerson, T. B., Sachse, G. W., Sedlacek, A. J., Shilling, J. E., Springston, S., Clair, J. M. St., Tanner, D. J., Teng, A. P., Wennberg, P. O., Wisthaler, A., and Wolfe, G. M.: Airborne measurements of western U.S. wildfire emissions: Comparison with prescribed burning and air quality implications, J. Geophys. Res.-Atmos., 122, 6108-6129, https://doi.org/10.1002/2016JD026315, 2017.

Macdonald, K. M., Sharma, S., Toom, D., Chivulescu, A., Hanna, S., Bertram, A. K., Platt, A., Elsasser, M., Huang, L., Tarasick, D., Chellman, N., McConnell, J. R., Bozem, H., Kunkel, D., Lei, Y. D., Evans, G. J., and Abbatt, J. P. D.: Observations of atmospheric chemical deposition to high Arctic snow, Atmos. Chem. Phys., 17, 5775-5788, https://doi.org/10.5194/acp17-5775-2017, 2017.

Masson-Delmotte, V., Schulz, M., Abe-Ouchi, A., Beer, J., Ganopolski, A., Rouco, J. F. G., Jansen, E., Lambeck, K., Luterbacher, J., Naish, T., Osborn, T., Otto-Bliesner, B., Quinn, T., Ramesh, R., Rojas, M., Shao, X., and Timmermann, A.: Information from paleoclimate archives, Climate change 2013: The Physical science basis, Contribution of working group I to the fifth assessment report of the Intergovernmental Panel on Climate Change, 383-464, https://doi.org/10.1017/CBO9781107415324.013, 2013.

May, A. A., McMeeking, G. R., Lee. T., Taylor, J. W., Craven, J. S., Burling, I., Sullivan, A. P., Akagi Jr., S., Collett, J. L., Flynn, M., Coe, H., Urbanski, S. P., Seinfeld, J. H., Yokelson,
R. J., and Kreidenweis, S. M.: Aerosol emissions from prescribed fires in the United States: A synthesis of laboratory and aircraftmeasurements, J. Geophys. Res.-Atmos., 119, 1182611849, https://doi.org/10.1002/2014JD021848, 2014.

McConnell, J. R., Edwards, R., Kok, G. L., Flanner, M. G., Zender, C. S., Saltzman, E. S., Banta, J. R., Pasteris, D. R., Carter, M. M., and Kahl, J. D. W.: 20th-Century industrial black carbon emissions altered Arctic climate forcing, Science, 317, 1381-1384, https://doi.org/10.1126/science.1144856, 2007.

McMeeking, G. R., Kreidenweis, S. M., Baker, S., Carrico, C. M., Chow, J. C., Collett, J. L., Hao, W. M., Holden, A. S., Kirchstetter, T. W., Malm, W. C., Moosmüller, H., Sullivan, A. P., and Wold, C. E.: Emissions of trace gases and aerosols during the open combustion of biomass in the laboratory, J. Geophys. Res.-Atmos., 114, 1-20, https://doi.org/10.1029/2009JD011836, 2009.

Mitchell, J. M.: Visual range in the polar regions with particular reference to the Alaskan Arctic, J. Atmos. Terr. Phys., 17, 195211, 1957.

Morin, S., Savarino, J., Frey, M. M., Yan, N., Bekki, S., Bottenheim, J. W., and Martins, J. M. F.: Tracing the origin and fate of NOx in the Arctic atmosphere using stable isotopes in nitrate, Science, 322, 730-732, https://doi.org/10.1126/science.1161910, 2008.

Mungall, E. L., Abbatt, J P. D., Wentzell, J. J. B., Lee, A. K. Y., Thomas, J. L., Blais, M., Gosselin, M., Miller, L. A., Papakyriakou, T., Willis, M. D., and Liggio, J.: Microlayer source of oxygenated volatile organic compounds in the summertime marine Arctic boundary layer, P. Natl. Acad. Sci. USA, 114, 6203-6208, https://doi.org/10.1073/pnas.1620571114, 2017.

Nguyen, Q. T., Skov, H., Sørensen, L. L., Jensen, B. J., Grube, A. G., Massling, A., Glasius, M., and Nøjgaard, J. K.: Source apportionment of particles at Station Nord, North East Greenland during 2008-2010 using COPREM and PMF analysis, Atmos. Chem. Phys., 13, 35-49, https://doi.org/10.5194/acp-13-352013, 2013.

Norris, G., Duvall, R., Brown, S., and Bai. S.: EPA Positive matrix factorization (PMF) 5.0 fundamentals and user guide, U.S. Environmental Protection Agency, 2014.

Paatero, P. and Hopke, P. K.: Discarding or downweighting highnoise variables in factor analytic models, Anal. Chim. Acta 490, 277-289, https://doi.org/10.1016/S0003-2670(02)01643-4, 2003.

Paris, J.-D., Stohl, A., Nédélec, P., Arshinov, M. Yu., Panchenko, M. V., Shmargunov, V. P., Law, K. S., Belan, B. D., and Ciais, P.: Wildfire smoke in the Siberian Arctic in summer: source characterization and plume evolution from airborne measurements, Atmos. Chem. Phys., 9, 9315-9327, https://doi.org/10.5194/acp9-9315-2009, 2009.

Paulot, F., Wunch, D., Crounse, J. D., Toon, G. C., Millet, D. B., DeCarlo, P. F., Vigouroux, C., Deutscher, N. M., González Abad, G., Notholt, J., Warneke, T., Hannigan, J. W., Warneke, C., de Gouw, J. A., Dunlea, E. J., De Mazière, M., Griffith, D. W. T., Bernath, P., Jimenez, J. L., and Wennberg, P. O.: Importance of secondary sources in the atmospheric budgets of formic and acetic acids, Atmos. Chem. Phys., 11, 1989-2013, https://doi.org/10.5194/acp-11-1989-2011, 2011.

Pratt, K. A., Custard, K. D., Shepson, P. B., Douglas, T. A., Pöhler, D., General, S., Zielcke, J., Simpson, W. R., Platt, U., Tanner, D. J., Gregory Huey, L., Carlsen, M., 
and Stirm, B. H.: Photochemical production of molecular bromine in Arctic surface snowpacks, Nat. Geosci., 6, 351-356, https://doi.org/10.1038/ngeo1779, 2013.

Pytkowicz, R. M. and Kester, D. R.: The Physical chemistry of sea water, Oceanogr. Mar. Biol., 9, 11-60, https://doi.org/10.1029/WR001i002p00263, 1971.

Quinn, P. K., Shaw, G., Andrews, E., Dutton, E. G., Ruoho-Airola, T., and Gong, S. L.: Arctic haze - Current trends and knowledge gaps, Tellus B, 59, 99-114, https://doi.org/10.1111/j.16000889.2006.00238.x, 2007.

Rahn, K. A.: Sources of trace elements in aerosols - An Approach to clean air, $\mathrm{PhD}$ thesis, University of Michigan, 1971.

Rahn, K. A., Borys, R., and Shaw, G. E.: The Asian source of Arctic Haze bands, Nature, 268, 713-715, https://doi.org/10.1038/268713a0, 1977.

Reff, A., Eberly, S. I., and Bhave, P. V.: Receptor modeling of ambient particulate matter data using positive matrix factorization: Review of existing methods, JAPCA J. Air Waste Ma., 57, 146154, https://doi.org/10.1080/10473289.2007.10465319, 2007.

Saarikoski, S., Sillanpaa, M., Sofiev, M., Timonen, H., Saarnio, K., Teinila, K., Karppinen, A., Kukkonen, J., and Hillamo, R.: Chemical composition of aerosols during a major biomass burning episode over northern Europe in spring 2006: Experimental and modelling assessments, Atmos. Environ., 41, 3577-3589, https://doi.org/10.1016/j.atmosenv.2006.12.053, 2007.

Sharma, S., Ishizawa, M., Chan, D., Lavoué, D., Andrews, E., Eleftheriadis, K., and Maksyutov, S.: 16-year simulation of arctic black carbon: Transport, source contribution, and sensitivity analysis on deposition, J. Geophys. Res.-Atmos., 118, 943-964, https://doi.org/10.1029/2012JD017774, 2013.

Shaw, G. and Wendler, G.: Atmospheric turbidity measurements at McCall Glacier in northern Alaska, B. Am. Meteorol. Soc., 53, 181-187, 1972.

Sirois, A. and Barrie, L. A.: Arctic lower tropospheric aerosol trends and composition at Alert, Canada: 1980-1995, J. Geophys. Res., 104, 11599-11618, https://doi.org/10.1029/1999JD900077, 1999.

Skeie, R. B., Berntsen, T., Myhre, G., Pedersen, C. A., Ström, J., Gerland, S., and Ogren, J. A.: Black carbon in the atmosphere and snow, from pre-industrial times until present, Atmos. Chem. Phys., 11, 6809-6836, https://doi.org/10.5194/acp11-6809-2011, 2011.

Slater, J. F., Currie, L. A., Dibb, J. E., and Benner, B. A.: Distinguishing the relative contribution of fossil fuel and biomass combustion aerosols deposited at Summit, Greenland through isotopic and molecular characterization of insoluble carbon, Atmos. Environ., 36, 4463-4477, https://doi.org/10.1016/S13522310(02)00402-8, 2002.

Stohl, A.: Characteristics of atmospheric transport into the Arctic troposphere, J. Geophys. Res.-Atmos., 111, 1-17, https://doi.org/10.1029/2005JD006888, 2006.

Stohl, A., Forster, C., Frank, A., Seibert, P., and Wotawa, G.: Technical note: The Lagrangian particle dispersion model FLEXPART version 6.2, Atmos. Chem. Phys., 5, 2461-2474, https://doi.org/10.5194/acp-5-2461-2005, 2005.

Stohl, A., Berg, T., Burkhart, J. F., Fjǽraa, A. M., Forster, C., Herber, A., Hov, Ø., Lunder, C., McMillan, W. W., Oltmans, S., Shiobara, M., Simpson, D., Solberg, S., Stebel, K., Ström, J., Tørseth, K., Treffeisen, R., Virkkunen, K., and Yttri, K. E.: Arctic smoke - record high air pollution levels in the European Arctic due to agricultural fires in Eastern Europe in spring 2006, Atmos. Chem. Phys., 7, 511-534, https://doi.org/10.5194/acp-7511-2007, 2007.

Stohl, A., Klimont, Z., Eckhardt, S., Kupiainen, K., Shevchenko, V. P., Kopeikin, V. M., and Novigatsky, A. N.: Black carbon in the Arctic: the underestimated role of gas flaring and residential combustion emissions, Atmos. Chem. Phys., 13, 8833-8855, https://doi.org/10.5194/acp-13-8833-2013, 2013.

Taylor, S. R.: Abundance of chemical elements in the continental crust: A New table, Geochim. Cosmochim. Ac., 28, 1273-1285, https://doi.org/10.1016/0016-7037(64)90129-2, 1964.

Toom-Sauntry, D. and Barrie, L. A.: Chemical composition of snowfall in the high Arctic: 1990-1994, Atmos. Environ., 36, 2683-2693, https://doi.org/10.1016/S1352-2310(02)00115$2,2002$.

Turn, S. Q., Jenkins, B. M., Chow, J. C., Pritchett, L. C., Campbell, D., Cahill, T., and Whalen, S. A.: Elemental characterization of particulate matter emitted from biomass burning: Wind tunnel derived source profiles for herbaceous and wood fuels, J. Geophys. Res.-Atmos., 102, 3683-3699, https://doi.org/10.1029/96JD02979, 1997.

VanCuren, R. A., Cahill, T., Burkhart, J., Barnes, D., Zhao, Y., Perry, K., Cliff, S., and McConnell, J. R.: Aerosols and their sources at Summit Greenland - First results of continuous size- and time-resolved sampling, Atmos. Environ., 52, 82-97, https://doi.org/10.1016/j.atmosenv.2011.10.047, 2012

Wang, Q., Jacob, D. J., Fisher, J. A., Mao, J., Leibensperger, E. M., Carouge, C. C., Le Sager, P., Kondo, Y., Jimenez, J. L., Cubison, M. J., and Doherty, S. J.: Sources of carbonaceous aerosols and deposited black carbon in the Arctic in winter-spring: implications for radiative forcing, Atmos. Chem. Phys., 11, 1245312473, https://doi.org/10.5194/acp-11-12453-2011, 2011.

Winiger, P., Andersson, A., Eckhardt, S., Stohl, A., Semiletov, I. P., Dudarev, O. V., Charkin, A., Shakhovac, N., Klimontf, Z., Heyesf, C., and Gustafsson, Ö.: Siberian Arctic black carbon sources constrained by model and observation, P Natl. Acad. Sci. USA, 114, E1054-E1061, https://doi.org/10.1073/pnas.1613401114, 2017.

Xu, J.-W., Martin, R. V., Morrow, A., Sharma, S., Huang, L., Leaitch, W. R., Burkart, J., Schulz, H., Zanatta, M., Willis, M. D., Henze, D. K., Lee, C. J., Herber, A. B., and Abbatt, J. P. D.: Source attribution of Arctic black carbon constrained by aircraft and surface measurements, Atmos. Chem. Phys., 17, 1197111989, https://doi.org/10.5194/acp-17-11971-2017, 2017.

Xu, L., Russell, L. M., Somerville, R. C. J., and Quinn, P. K.: Frost flower aerosol effects on arctic wintertime longwave cloud radiative forcing, J. Geophys. Res.-Atmos., 118, 13282-13291, https://doi.org/10.1002/2013JD020554, 2013.

Ye, P., Xie, Z., Yu, J., and Kang, H.: Spatial distribution of methanesulphonic acid in the Arctic aerosol collected during the Chinese Arctic research expedition, Atmosphere, 6, 699-712, https://doi.org/10.3390/atmos6050699, 2015.

Yttri, K. E., Simpson, D., Nøjgaard, J. K., Kristensen, K., Genberg, J., Stenström, K., Swietlicki, E., Hillamo, R., Aurela, M., Bauer, H., Offenberg, J. H., Jaoui, M., Dye, C., Eckhardt, S., Burkhart, J. F., Stohl, A., and Glasius, M.: Source apportionment of the summer time carbonaceous aerosol at Nordic ru- 
ral background sites, Atmos. Chem. Phys., 11, 13339-13357, https://doi.org/10.5194/acp-11-13339-2011, 2011.

Yttri, K. E., Lund Myhre, C., Eckhardt, S., Fiebig, M., Dye, C., Hirdman, D., Ström, J., Klimont, Z., and Stohl, A.: Quantifying black carbon from biomass burning by means of levoglucosan - a one-year time series at the Arctic observatory Zeppelin, Atmos. Chem. Phys., 14, 6427-6442, https://doi.org/10.5194/acp14-6427-2014, 2014.
Zwaaftink,C. D. G., Grythe, H., Skov, H., and Stohl, A.: Substantial contribution of northern high-latitude sources to mineral dust in the Arctic, J. Geophys. Res.-Atmos., 121, 13678-13697, https://doi.org/10.1002/2016JD025482, 2016. 